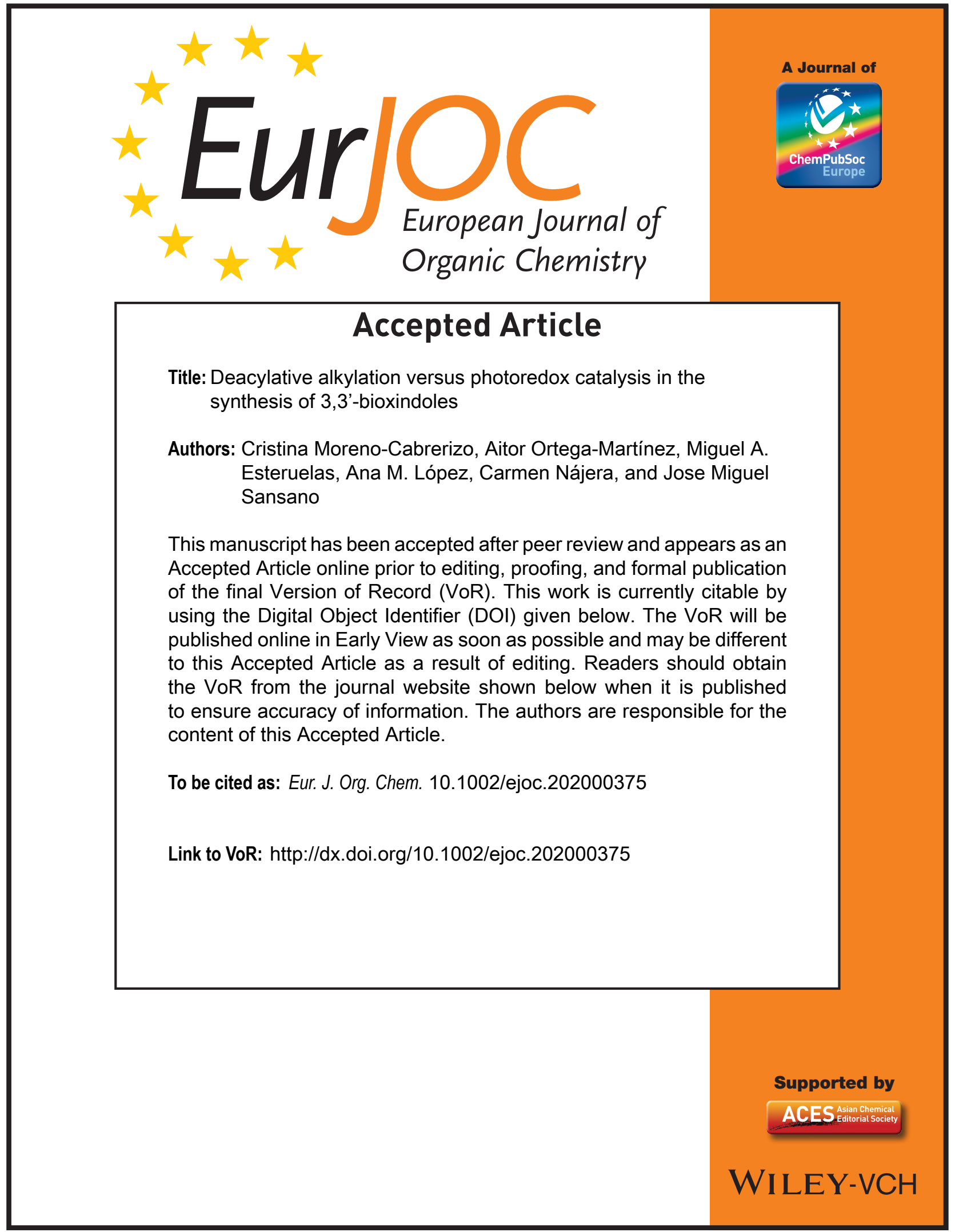




\title{
Deacylative alkylation versus photoredox catalysis in the synthesis of 3,3'-bioxindoles
}

\author{
Cristina Moreno-Cabrerizo, ${ }^{[a, b]}$ Aitor Ortega-Martínez, ${ }^{[a, b]}$ Miguel A. Esteruelas, ${ }^{[b, c]}$ Ana M. López, ${ }^{[b, c]}$ \\ Carmen Nájera, ${ }^{[b]}$ José M. Sansano. ${ }^{* a, b]}$
}

Abstract: The synthesis of 3,3'-bioxindoles employing deacylative alkylations (DaA) in one-pot process, where the 3-bromooxindoles are generated in situ, is described. Good yields and moderate diastereoselections are obtained. By the modification of this procedure the synthesis of pure 3-bromooxindoles through a deacylative bromination $(\mathrm{DaB})$ is achieved. These bromides are efficiently employed in a photoredox dimerization process to get the desired 3,3'-bioxindoles in good yields and low diastereoselections. In this single-electron-transfer (SET) mechanism the presence of a high quantum-yield iridium(III) complex ensures high conversions in short reaction times.

\section{Introduction}

The synthesis of 3,3'-bioxindoles has been widely documented. There are five general strategies (Scheme 1) to achieve these systems. The oxidative coupling between two 3-substituted oxindoles allows the preparation of these structures with the same substituents, via radical intermediates, employing transition metal catalysts ${ }^{[1,2]}$ or not $^{[3]}$ (Scheme 1a). Isoindigo (obtained from isatin and oxindole) is a very common starting material for the synthesis of dimeric oxindoles as intermediates for the construction of complex natural structures. These isoindigo derivatives can be used as electrophilic alkenes ${ }^{[4]}$ or a bis-enolate precursor after selective hydrogenation of the carbon-carbon double bond ${ }^{[5]}$ (Scheme 1b). Electron-deficient 3alkylidene oxindoles have been involved in [2+2] photochemical transformations promoted by an energy transfer mechanism, ${ }^{[6]}$ and as Michael-type acceptor with Morita-Baylis-Hillman (MBH) systems, ${ }^{[7]}$ with alkoxycarbonylmethyl-pyridinium bromides, ${ }^{[8]} 3$ substituted oxindoles, ${ }^{\left[{ }^{[9]}\right.}$ the Hantzsch ester, ${ }^{[10]}$ nitromethane,${ }^{[11]}$ and with alkyl phosphites ${ }^{[12]}$ to access finally the desired dimeric unit (Scheme 1c). ${ }^{13}$ Starting from 3-(3-indolyl)oxindoles by

[a] Ms. C. Moreno-Cabrerizo, Dr. A. Ortega-Martínez, Prof. J. M. Sansano

University of Alicante, Department of Organic Chemistry, and Instituto de Síntesis Orgánica (ISO), PO Box 99, 03080 Alicante, Spain.

[b] Ms. C. Moreno-Cabrerizo, Dr. A. Ortega-Martínez, Prof. M. A Esteruelas, Prof. A. M. López, Prof. C. Nájera, Prof. J. M. Sansano Centro de Innovación en Química Avanzada (ORFEO-CINQA)

[c] Prof. M. A. Esteruelas, Prof. A. M. López

Departamento de Química Inorgánica

Instituto de Síntesis Química y Catálisis Homogénea

Universidad de Zaragoza-CSIC, 50009 Zaragoza, Spain.

https://cvnet.cpd.ua.es/curriculum-breve/es/sansano-gil-josemiguel/10547

Corresponding author: jmsansano@ua.es

Supporting information for this article is given via a link at the end of the document. functional groups transformation non-symmetrically substituted 3,3'-bisoxindoles can be obtained (Scheme 1d). ${ }^{[14]}$ The last strategy consists in an intramolecular dehydrogenative coupling (IDC) from the corresponding functionalized $\mathrm{N}$-acylanilines or the 0 -iodo/triflate substituted surrogates. In the first case, a radical $\mathrm{C}-\mathrm{H}$ bond activation is followed by the coupling with the activated methylene group, ${ }^{[15]}$ whilst intramolecular MizorokiHeck reaction control the IDC process in the second case (Scheme 1e). ${ }^{[16]}$

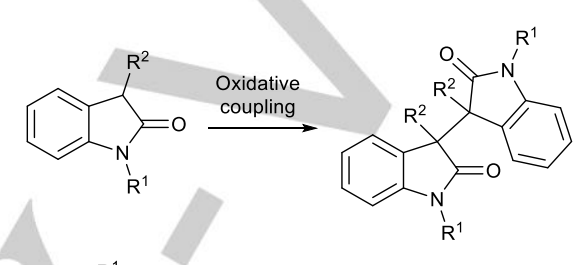

a)
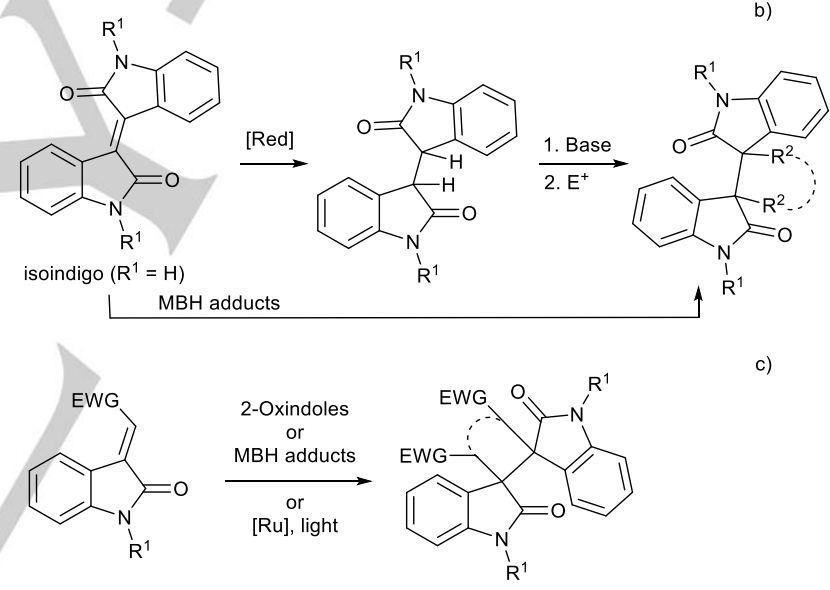

c)

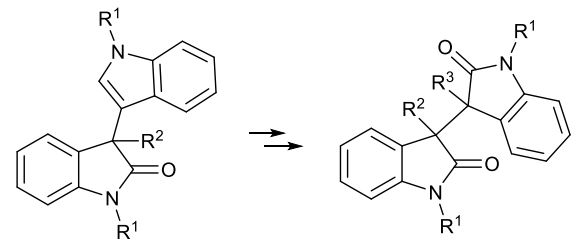

d)

e)

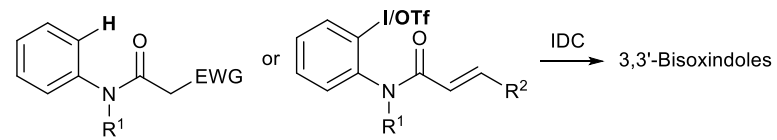

Scheme 1. General strategies employed for the synthesis of 3,3'-bioxindoles.

The main interest of the synthesis of 3,3'-bioxindoles is focused on the preparation of very sophisticated natural products (1-10, Figure 1) as, for example, pyrroloindole alkaloids of the Calycanthaceae family such as (+)-chimonanthine 1, ${ }^{[3 \mathrm{~b}, \mathrm{c}, 4 \mathrm{~b}, \mathrm{c}, 5 \mathrm{e}-\mathrm{h}, 14 \mathrm{a}, \mathrm{c}, \mathrm{d}, 15 \mathrm{a}]}(+)$-chimonanthidine $2,{ }^{[5 \mathrm{~g}]}(+)$-calycanthidine $\mathbf{3}^{[17]}(+)$-folicanthine $4,{ }^{[3 a, b, f, 4 b, 5 f, h, i, 14 a, b, d, e, h, 15 a]}$ and (+)-calycanthine $\mathbf{5}^{[3 \mathrm{3f}, 4 \mathrm{~b}, 5 \mathrm{ff}, \mathrm{h}, 14 \mathrm{~d}]}$ which exhibit diverse therapeutic properties as analgesics, antibacterials, antifungals and antivirals. ${ }^{[18]}(+)-$ 
Perophoramidine $6^{[14 f]}$ exhibits cytotoxicity toward the HCT 116 human colon carcinoma cell line $\left(\mathrm{IC}_{50}=60 \mu \mathrm{M}\right)$ and induces apoptosis via poly(ADP-ribose) polymerase (PARP) cleavage. ${ }^{[14]}$ (-)-Idiospermuline $7,{ }^{[5 b, c]}$ a polypyrroloindoline natural alkaloid, exhibits hyperpolarization activity on neurochemical transmission in Sprague-Dawley rat cortical wedge. ${ }^{[18,19]}(+)-$ Communesin $\mathrm{F} \mathrm{8,}{ }^{\left[{ }^{14 f]}\right.}$ for example, is a complex polycyclicindole alkaloid with cytotoxicity against P388 lymphocytic leukemia cells $\left(E D_{50} A: 3.5 \mu \mathrm{g} / \mathrm{mL}, \mathrm{B}: 0.45 \mu \mathrm{g} / \mathrm{mL}\right.$ ) and potent insecticidal activity toward silk-worms (LD 50 D: $300 \mu \mathrm{g} / \mathrm{g}, \mathrm{E}: 80 \mu \mathrm{g} / \mathrm{g}){ }^{\left[{ }^{20]}\right.}$ Tryptophan-based dimeric diketopiperazine alkaloids ${ }^{21]}$ (-)ditryptophenaline $\mathbf{9}^{[4 \mathrm{~b}, 5 \mathrm{f}, \mathrm{j}, 15 \mathrm{a}]}$ and (-)-WIN $64821 \mathbf{1 0}^{[4 \mathrm{~b}, 5 \mathrm{ff}, \mathrm{j}, 15 \mathrm{a}]}$ were isolated from Aspergillus oryzae and sp. SC319, respectively. Specially, compound $\mathbf{1 0}$ is competitive substance $P$ antagonist with submicromolar potency against the human neurokinin 1 (NK1) receptor and also an antagonist of the cholecystokinin type-B receptor. $\left.{ }^{[5]}\right]$

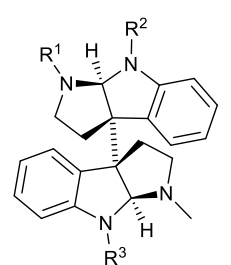

$R^{3}$
(+)- Chimonanthine 1; $\mathrm{R}^{1}=\mathrm{Me}, \mathrm{R}^{2}, \mathrm{R}^{3}=\mathrm{H}$ (+)- Chimonanthidine $2 ; R^{1}=H, R^{2}, R^{3}=M e$ (+)- Calycanthidine $3 ; R^{1}, R^{2}=M e, R^{3}=H$ $(+)$ - Folicanthine $4 ; R^{1}, R^{2}, R^{3}=M e$

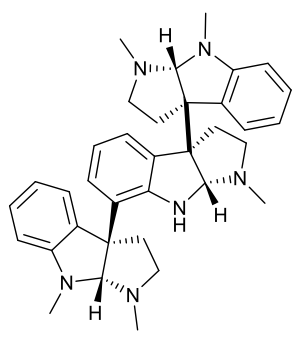

(-)-Idiospermuline 7

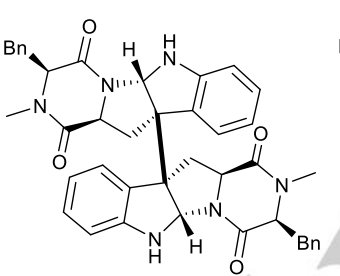

(-)-Ditryptophenaline 9

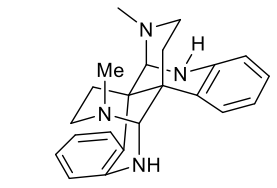

(+)-Calycanthine 5

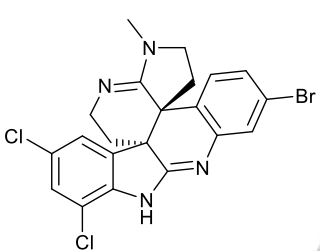

(+)-Perophoramidine 6

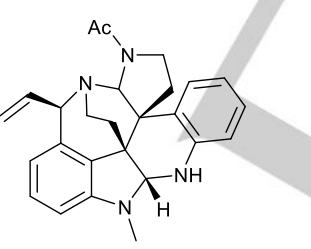

(+)-Communesin F 8

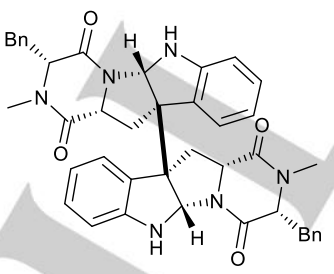

(-)-WIN 6482110
Figure 1. Natural products synthesized from 3,3'-bioxindoles.

This paper describes a successful access to the bioxindole bridge employing the deacylative alkylation $(\mathrm{DaA})^{[22]}$ studied by our group ${ }^{[23]}$ and its comparison with a photoredox version employing 3-bromo-3-substituted oxindole derivatives, which are obtained by an original procedure involving deacylative bromination (DaB), and a new iridium(III) photocatalyst recently reported.

\section{Results and Discussion}

The initial attempt to get dimers 11 consisted in the reaction between the 3-acetyl-3-substituted oxindoles 12 as nucleophiles and the corresponding umpolung bromides 13 as electrophiles (Scheme 2). The already known heterocycles 12 were prepared from 3-acetyloxindoles $\mathbf{1 4}$ using tetrabutylammonium hydroxide (Triton B) as base together with the alkylating agent (Scheme 3). ${ }^{[23 a-c]}$ This DaA afforded good to excellent yields of the desired products after column chromatography.

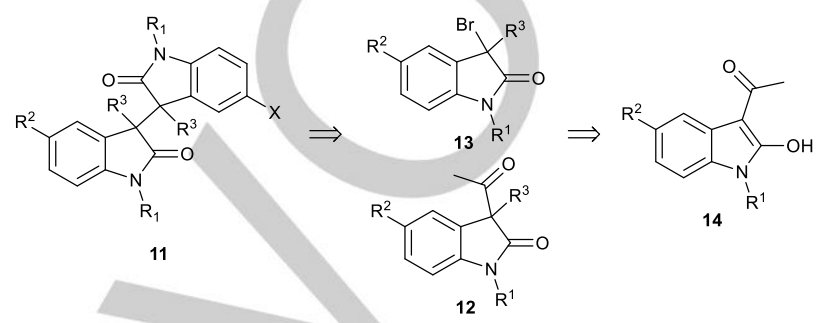

Scheme 2. Retrosynthetic analysis for the ionic synthesis of 3,3'-bioxindoles.

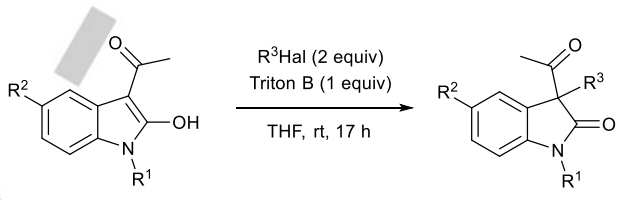

14

12<smiles>COc1ccc2c(c1)C(C)(C(C)=O)C(=O)N2C</smiles><smiles>COc1ccc2c(c1)C(C)(C(C)=O)C(=O)N2Cc1ccccc1</smiles><smiles>C=CCC1(C(C)=O)C(=O)N(C)c2ccc(OC)cc2C1(CC=C)C(C)=O</smiles>

$12 \mathrm{c}(60 \%)$

$12 d(68 \%){ }^{B}$<smiles>C=CCC1(C(C)=O)C(=O)N([13C](C)([13CH3])[18OH])c2ccccc21</smiles><smiles>C=CCC1(C(C)=O)C(=O)N(Cc2ccccc2)c2ccc(OC)cc21</smiles>

12h $(94 \%)$

Scheme 3. Synthesis of the starting compounds 12 by base promoted DaA.

The synthesis of the 3-bromooxindole derivatives 13 was attempted using two different approaches (Scheme 4). The first way consisted in a halogenation-DaA sequence following the reaction conditions used for the preparation of the corresponding 3-fluoro-3-substituted oxindole derivatives under very mild conditions. ${ }^{[23 \mathrm{~d}]}$ Thus, compound $15 \mathrm{a}$ was obtained almost quantitatively using $\mathrm{N}$-bromosuccinimide (NBS) and $\mathrm{MgClO}_{4}(20$ mol\%) in very short reaction time and did not require additional purification. The DaA of $15 a$ employing Triton $B$ and methy iodide afforded a very complex reaction mixture and no evidence of compound 13a was detected in the ${ }^{1} \mathrm{H}$ NMR spectra of the reaction crudes (Scheme 4a). Other bases, such as LiOEt and potassium tert-butoxide, in the range from $0 \stackrel{\circ}{\circ}$ to room temperature were also unsuccessfully tested. So, a second strategy performing the bromination step at the end of the sequence was designed (Scheme 4b). The already prepared 3 acetyl-3-methyloxindole derivative 12a was allowed to react with 
$\mathrm{N}$-bromosuccinimide (NBS) in the presence of Triton B or LiOEt (0.1 M solution in THF) affording a $10 \%$ or a $58 \%$ yield of brominated species $13 a$, respectively.

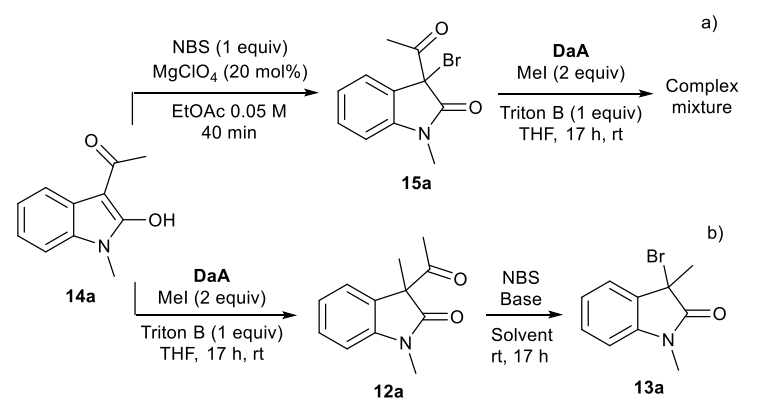

Scheme 4. Two possible routes to access compound 13a.

At this point, we considered that an optimization of this bromination step was needed (Table 1). Initially, THF was selected as solvent because the commercially available LiOEt was dissolved on it. In addition, DCM or toluene was added as co-solvent. However, all attempts led to complex reaction mixtures, which were difficult to analyze by ${ }^{1} \mathrm{H}$ NMR spectroscopy. The reaction using wet THF and air gave a mixture of the four compounds shown in Table 1 (entries 1 and 2) independently of the amount of NBS. Using anhydrous THF and running the reaction under an argon atmosphere, the formation of both undesired deacylated oxindole 17a and the 3hydroxy derivative 16a was suppressed, being the amount of bromide 13a higher when added 2 equiv of NBS and the freezing-pump technique was applied (Table 1, entries 3-6). The effect of lowering the temperature was not beneficial (Table 1, entry 7), but, gratifyingly, in $15 \mathrm{~min}$ the reaction was completed and the amount of the dimeric product 11a was relatively small (Table 1, entry 8 ). However, the generation of 11 a as major product was achieved employing 0.5 equiv of NBS under anhydrous conditions, without the previous freezing-pump operation (Table 1, entry 9). Employing $N$-iodosuccinimide, instead of NBS, in short reaction times (15 min) afforded very clean reaction crude, which contained almost exclusively dimer 11a (Table 1, entry 10). In this last example a deacylative iodination (Dal) occurred instead.

Table 1. Optimization of the deacylative bromination (DaB) of oxindole derivative $\mathbf{1 2 a}$.

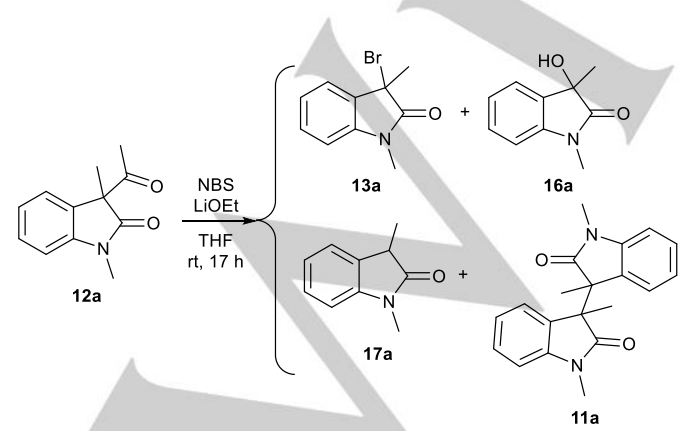

\begin{tabular}{|c|c|c|c|c|c|c|c|}
\hline & (equiv) & (equiv) & & & & & \\
\hline 1 & 1.1 & 1 & --- & 3 & 54 & 14 & 19 \\
\hline 2 & 1.5 & 1 & --- & 15 & 50 & 12 & 9 \\
\hline 3 & 1.5 & 1.2 & ${ }^{\mathrm{anh}} \mathrm{THF}, \mathrm{Ar}$ & 58 & 11 & 7 & --- \\
\hline 4 & 1 & 1.1 & ${ }^{\text {anh }} \mathrm{THF}, \mathrm{Ar}$ & 44 & 56 & --- & --- \\
\hline 5 & 1 & 1.1 & ${ }^{a n h} T H F, A r^{[b]}$ & 58 & 42 & --- & --- \\
\hline 6 & 2 & 1 & anh $T H F, A r^{[b]}$ & 88 & 12 & --- & --- \\
\hline 7 & 2 & 1 & ${ }^{a n h} T H F, A r^{[b, c]}$ & 75 & 25 & --- & --- \\
\hline 8 & 2 & 1 & ${ }^{a n h} T H F, A r^{[b, d]}$ & 88 & 12 & --- & --- \\
\hline 9 & 0.5 & 1 & ${ }^{a n h} \mathrm{THF}, \mathrm{Ar}$ & 8 & 92 & --- & -- \\
\hline 10 & 0.5 & 1 & ${ }^{a n h} \mathrm{THF}, \mathrm{Ar}[\mathrm{e}]$ & --- & 95 & --- & -- \\
\hline
\end{tabular}

[a] Ratios/percentages determined by ${ }^{1} \mathrm{H}$ NMR analysis of the crude mixtures. The remaining percentage (not shown) corresponds to the recovered starting material 12a. [b] The reaction solution was deoxygenated using freezing-pump technique. [c] Reaction performed at $0 \stackrel{\circ}{\mathrm{C}}$. [d] Reaction performed in $15 \mathrm{~min}$. [e] $N$-lodosuccinimide (NIS) was used instead of NBS.

Using this last reaction conditions, the preparation of symmetrically substituted 3,3'-bioxindoles $\mathbf{1 1}$ was achieved directly, in a one pot process, where the electrophile was generated in situ (it was not necessary to isolate the corresponding iodide) in the presence of the enolate emulating the classical Barbier conditions. Thus, 3,3'-bioxindoles 11a-h were isolated in very good and modest yields (90-26\%) (Scheme $5)$. In these examples, different substituents at 1,3 and 5 positions of the heterocycle were evaluated and the diastereoselection was always $\left(R^{*}, R^{*}\right)$ :meso $3: 1$ (determined by ${ }^{1} \mathrm{H}$ NMR spectroscopy on the crude mixture). It is noticeable that in this cascade reaction two different deacylative processes occurred, the Dal took place and immediately, and the DaA completed the sequence. After flash chromatography, only the major $\left(R^{*}, R^{*}\right)$-diastereoisomer $\mathbf{1 1}$ was isolated as pure diastereoisomer. 

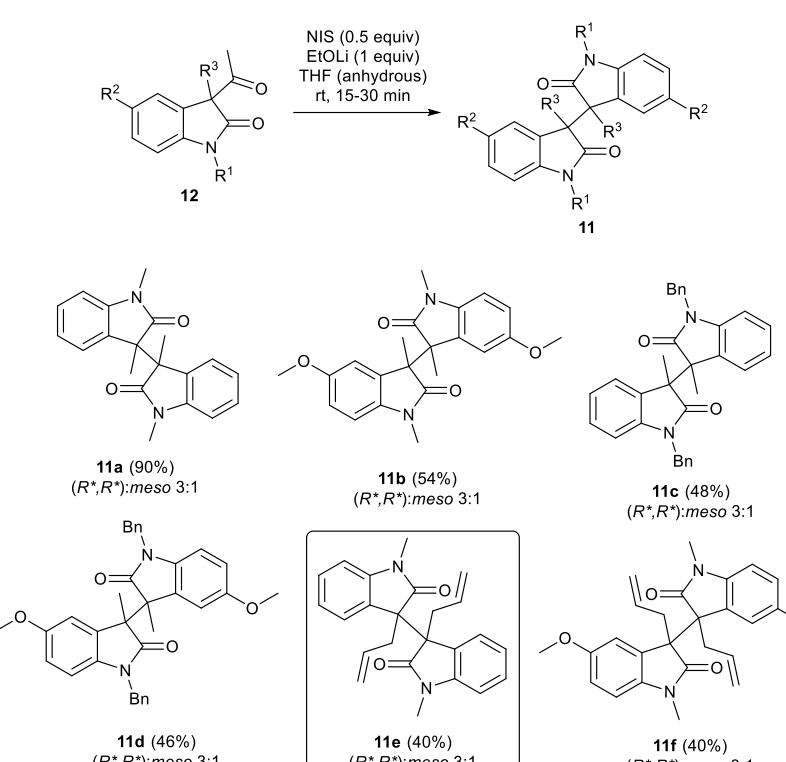

Bn

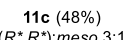
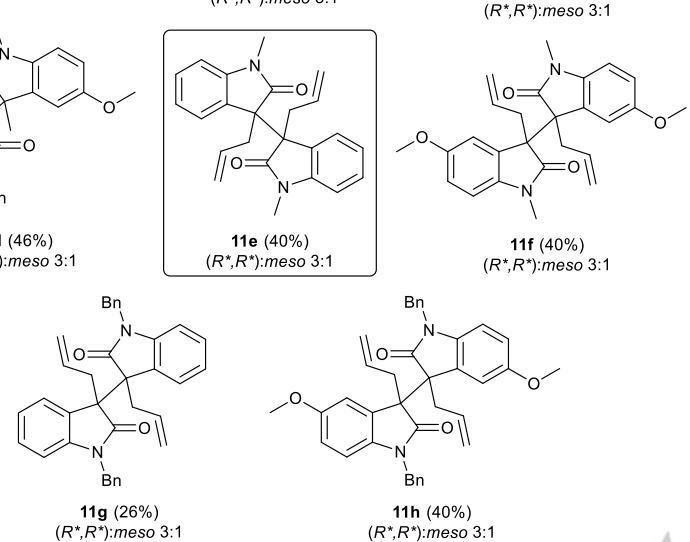

Scheme 5. Synthesis of 11a-h using a combined sequential Dal-DaA.

Such as it was described, 3-chloro-3-substituted oxindoles were successfully homocoupled via visible light photocatalysis (method not shown in Scheme 1) using fac-Ir(ppy) . $^{[24]}$ So, we envisaged the same transformation but using the bromides 13 instead. Turning back to the best result of the Table 1 (entry 8), the synthesis of 3-bromo-3-substituted oxindoles 13 was accomplished after 15-20 min, by the novel DaB; using 1 equiv of LiOEt and 1.1 equiv of NBS, at room temperature, under an argon atmosphere. The THF solutions (the base-containing solution and the reaction mixture) were previously submitted to a freezing-pump deoxygenation. After purification by flash chromatography, bromides 13 were isolated as pure compounds in good chemical yields (Scheme 6). These results were completely reproducible, even the synthesis of compound 13a was scaled up to $0.5 \mathrm{~g}(2.4 \mathrm{mmol})$. This new procedure did not required strong basic conditions, ${ }^{[24]}$ the employment of diazocompounds ${ }^{[} \quad 25 \quad$ ] or hazardous tris(dimethylamino)phosphine. ${ }^{[26]}$

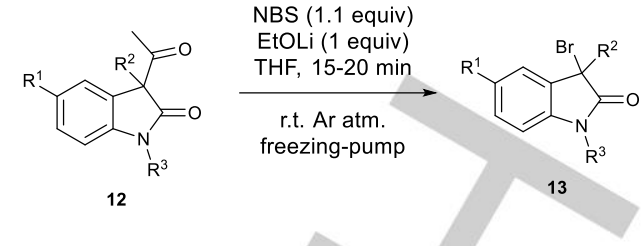<smiles>CN1C(=O)C(C)(Br)c2ccccc21</smiles><smiles>C/C=C/C=C/C</smiles>

$$
\text { 13a, } 70 \%
$$

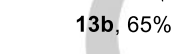<smiles>CC(C)(C)CCN1C(=O)C(C)(Br)c2ccccc21</smiles><smiles>COc1ccc2c(c1)C(C)(Br)C(=O)N2Cc1ccccc1</smiles><smiles>C=CCC1(Br)C(=O)N(CC)c2ccccc21</smiles>

$13 e, 45 \%$ $13 f, 60 \%$

$13 \mathbf{g}, 51 \%$

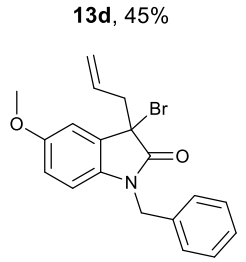

$13 \mathrm{~h}, 83 \%$

Scheme 6. Synthesis of 3-bromooxindoles 13a-h using a DaB process.

Bromide 13a was submitted to the optimization of solvents, source of light, catalysts, base and electron donor. We initially took the conditions reported previously employing a blue LED source in acetonitrile, with the base DBU as electron donor. [24] Under these conditions, photocatalyst 18 afforded a modest yield $(45 \%)$ with high amounts of the oxidized product 16a (Table 2 , entry 1). Ruthenium(II) complex 19, as well as organophotocatalyst Eosin B (this last example is not shown in the Table 2) did not promote the reaction at all. In view of this situation, we decided to employ recently reported organometallic phosphorescent compounds as new photocatalysts (Table 2 , entries 3-6): the homoleptic osmium(II) complex 20 bearing two equal 5-electron donor C,C,C-pincer ligands based on bis-NHC systems, ${ }^{[27]}$ the heretoleptic iridium(III) derivatives 21 and 22 containing a 6-electro donor C,C,C,C-tetradentate group and a 3-electron donor orthometalated phenylpyridine, ${ }^{[28]}$ and the heteroleptic compound $\mathbf{2 3}$ stabilized by a 5-electron donor N,C,N-pincer ligand and a 4-electron donor C,N,C-group. ${ }^{[29]}$ The osmium complex $\mathbf{2 0}$ is a blue emitter in 2-methyl tetrahydrofuran, which displays a quantum yield of 0.62 in the solid state. Under the same conditions, the iridium complexes 21 and 22 are bluegreen emitters with quantum yields close to unity, whereas complex $\mathbf{2 3}$ is green emissive with a quantum yield of 0.87 . The best conversion and chemical yield of 11a were achieved by intermediacy of catalyst $\mathbf{2 3}$ (Table 2, entry 6).In this context, it should be mentioned that in addition to the lower energy of its emission, complex 23 shows two noticeable differences with regard to $\mathbf{2 1}$ and $\mathbf{2 2}$. It displays longer lifetime in 2methyltetrahydrofuran, at room temperature $(2.4$ and $1.6 \mu \mathrm{s}$, respectively, versus $7.7 \mu \mathrm{s}$ ) and the presence of an oxygen atom between the pyridyl ring and one of the phenyl group of the C,N,C-pincer ligand, which stabilizes the octahedral geometry of the catalyst, due to the increase of a N-Ir-C bite angle. ${ }^{[30]}$ The 24 $W$ blue LED source afforded better conversions than the visible light, $20 \mathrm{~W}$ fluorescent bulb, or $20 \mathrm{~W}$ white bulb (not included in 
Table 2). Despite diisopropylethylamine (DIPEA) did not give satisfactory results in acetonitrile, in THF afforded similar results than the obtained one in the reaction with DBU (compare entries 8-10 of the Table 2). Here, the freezing-pump operation resulted to be crucial to diminish the percentage of the oxidized compound 16a. DIPEA was selected as base because the crude reaction mixture was very clean (detected by ${ }^{1} \mathrm{H}$ NMR) unlike the reaction crude generated from $\mathrm{DBU}$. The conversion and the yield of product 11a were improved employing freshly distilled DIPEA (under anhydrous conditions). All 11a products identified in the crude mixtures or isolated in this Table 2 resulted to be $1: 1$ mixtures of $\left(R^{*}, R^{*}\right)$ :meso diastereoisomers according to ${ }^{1} \mathrm{H}$ NMR data.

Table 2. Optimization of the synthesis of 3,3'-bioxindole 11a via photoredox catalysis.

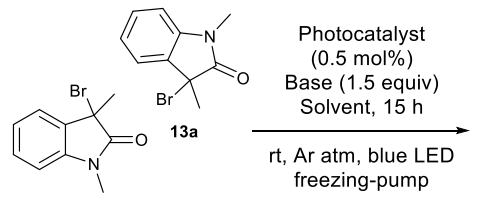

13a

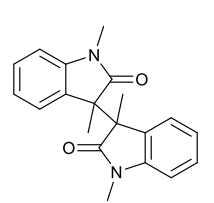

$11 \mathrm{a}$
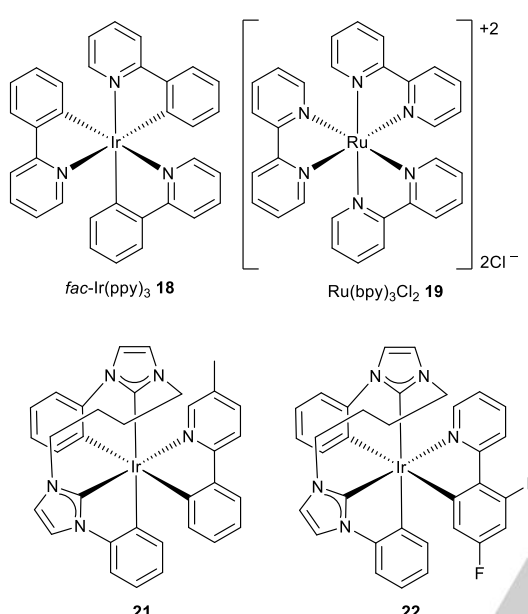

21

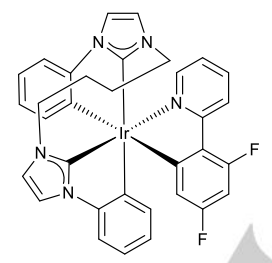

22

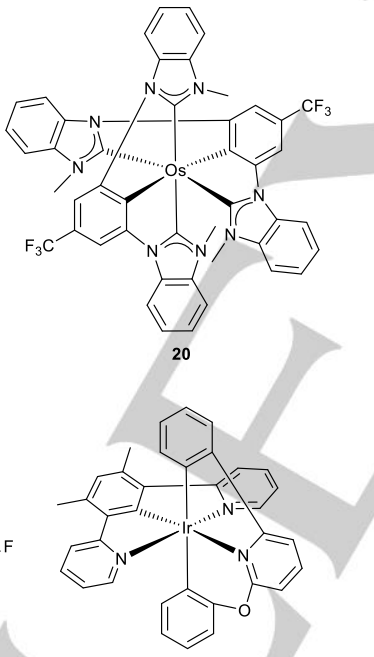

23

\begin{tabular}{|c|c|c|c|c|c|c|c|}
\hline & Catalyst & Base & $\begin{array}{l}\text { Solvent } \\
(0.1 \mathrm{M})\end{array}$ & $11 a^{[a]}$ & $13 a$ & $16 a$ & $\begin{array}{l}\text { Yield } \\
(\%)^{[b]}\end{array}$ \\
\hline 1 & 18 & DBU & $\mathrm{MeCN}$ & 66 & 4 & 30 & 45 \\
\hline 2 & 19 & DBU & $\mathrm{MeCN}$ & trace & 85 & 15 & -- \\
\hline 3 & 20 & DBU & $\mathrm{MeCN}$ & trace & 90 & 10 & -- \\
\hline 4 & 21 & DBU & $\mathrm{MeCN}$ & 22 & 65 & 13 & --- \\
\hline 5 & 22 & DBU & $\mathrm{MeCN}$ & 40 & 36 & 24 & --- \\
\hline 6 & 23 & DBU & $\mathrm{MeCN}$ & 72 & 16 & 12 & 56 \\
\hline 7 & $23^{[c]}$ & DBU & $\mathrm{MeCN}$ & 78 & 12 & 10 & 58 \\
\hline 8 & $23^{[c]}$ & DIPEA & $\mathrm{MeCN}$ & 25 & 50 & 25 & --- \\
\hline 9 & $23^{[c]}$ & DIPEA & THF & 85 & -- & 15 & 68 \\
\hline 10 & $23^{[c]}$ & DBU & THF & 88 & --- & 12 & 69 \\
\hline 11 & $23^{[c]}$ & DIPEA $^{[\mathrm{d}]}$ & THF & 93 & --- & 7 & 73 \\
\hline 12 & $23^{[\mathrm{c}][\mathrm{e}]}$ & DIPEA $^{[\mathrm{d}]}$ & THF & 93 & -- & 7 & 73 \\
\hline 13 & -- & DIPEA $^{[\mathrm{d}]}$ & THF & 10 & 67 & 23 & --- \\
\hline 14 & $23^{[\mathrm{c}][\mathrm{f}]}$ & DIPEA $^{[d]}$ & THF & trace & 80 & 10 & --- \\
\hline
\end{tabular}

$\begin{array}{llllllll}15 & \mathbf{2 3}^{[c]} & --- & \text { THF } & \text { trace } & 19 & 52 & -- \\ 16 & \mathbf{2 3} & \text { DIPEA }^{[d]} & \text { THF } & 79 & -- & 21 & --- \\ 17 & \mathbf{2 3}^{[c]} & \text { DIPEA }^{[d][g]} & \text { THF } & \text { trace } & 80 & 20 & ---\end{array}$

[a] A 1:1 $\left(R^{\star}, R^{*}\right)$ :meso diastereomeric ratio was determined by ${ }^{1} \mathrm{H}-\mathrm{NMR}$ analysis of the crude mixtures. The remaining percentage (not shown) corresponds to the recovered starting material 12a. [b] Isolated yield after flash chromatography. [c] The reaction solution was deoxygenated using freezingpump technique. [d] Freshly distilled and working under anhydrous conditions. [e] $1 \mathrm{Mol} \%$ of the catalyst was added. [f] In the absence of blue-LED light. [g] TEMPO (20 mol\%) was added.

The catalysis can be rationalized according to Scheme 7 . The excited state of $\mathbf{2 3}$ is highly reductant and could be quenched by 13a faster than by DIEPA through a SET step. The collision should lead to a cation radical iridium(IV) species, a bromide ion, and a radical oxindole The iridium(III) fundamental state would be regenerated by means of the reaction of DIPEA with the cation radical iridium(IV) species in a second SET stage. The resulting radical cation [DIPEA $]^{+}$should release a radical $\mathrm{H}^{*}$, to afford an iminium cation. Then, the radical $\mathrm{H}^{\cdot}$ could be trapped by a radical $\mathrm{Br}$, which should be generated in the collision between the radical oxindole and a second molecule of 13a, to form the carbon-carbon bond of 11a.

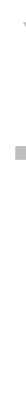

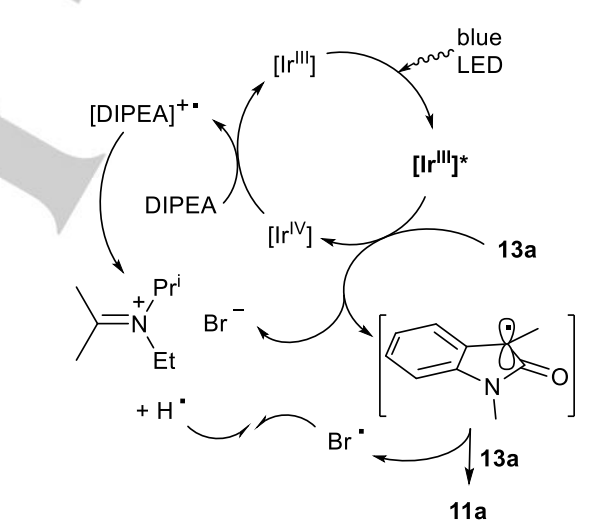

Scheme 7. Mechanistic proposal for the synthesis of 11a.

The efficient dimerization took place under anhydrous conditions, under argon atmosphere, with the catalytic complex 23 ( $0.5 \mathrm{~mol} \%)$ and DIPEA (1.5 equiv), after $15 \mathrm{~h}$ irradiation with $24 \mathrm{~W}$ blue LED, at room temperature. Previously, all solutions were submitted to the freezing-pump protocol. Products 11 were obtained in good to moderate chemical yield and as almost 1:1 $\left(R^{*}, R^{*}\right)$ :meso ratios (Scheme 8). These results compare well with those obtained from 3-chlorooxindoles and the photocatalyst 18. ${ }^{[24]}$ Compound 11e was isolated in $70 \%$ yield and as 1.2:1 $\left(R^{\star}, R^{\star}\right)$ :meso ratio (Scheme 8), whereas a 3:1 $\left(R^{\star}, R^{\star}\right)$ :meso ratio and a $40 \%$ yield was obtained using the combined sequential Dal-DaA methodology (Scheme 5). At this point, $\left(R^{*}, R^{*}\right)$ - and meso-diastereoisomers 11a-d were separated as pure compounds after flash chromatography. However, for allylated derivatives $11 \mathrm{e}-\mathrm{h}$ only the $\left(R^{\star}, R^{\star}\right)$-isomers were obtained as pure final compounds and the mesosurrogates were impurified with their corresponding $\left(R^{\star}, R^{\star}\right)$ diasteroisomer. Compound $11 \mathrm{e}$ is the key building block for the synthesis of (-)-chimonanthine (ent-1), (+)-calycanthine (5), (-)- 
WIN 64821 (10), and (-)-ditryptophenaline (9) $)_{\overline{5}}^{[15 a]}$ and a potential precursor of $( \pm)$-dehaloperophoramidines ${ }^{[4 \mathrm{~d}]}$ and certain communesins. ${ }^{[9 \mathrm{~d}]}$
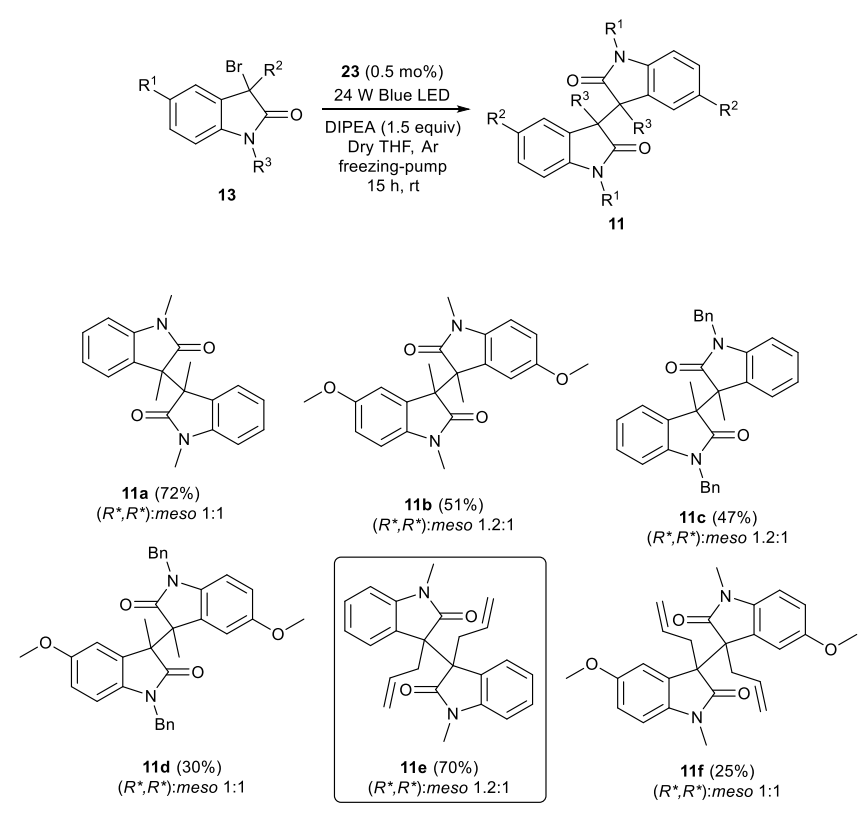

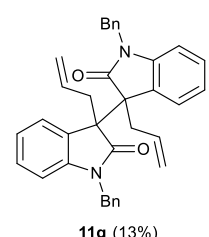

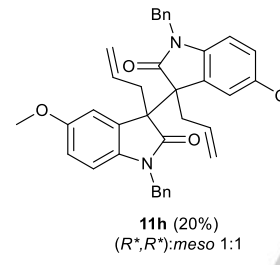

Scheme 8. Synthesis of 11a-h using a photoredox catalysis from $\mathbf{1 3}$.

\section{Conclusion}

In conclusion, the efficient synthesis of 3,3'-bioxindoles or 3-bromosubstituted oxindoles can be selectively performed using small differences in the amount of NBS employed. This is a clear example of diverse oriented synthesis (DOS). It should be also noted that the deacylative alkylation $(\mathrm{DaA})$ of the in situ generated bromides constitute a very easy and original methodology to reach these attractive symmetrically substituted 3,3'-bioxindoles. The method improves previously reported procedures by increasing the yields and purity of the products. Deacylative bromination ( $\mathrm{DaB})$, a novel synthetic protocol to prepare 3-bromo-3-substituted oxindoles with high yields, under mild conditions, has been developed. In both deacylative processes no harsh reaction conditions are required. In addition, the photoredox catalyzed version of the dimerization has been successfully evaluated using an unprecedented iridium(III) photocatalyst. The results of the catalysis compare well with those obtained from 3-chlorooxindoles and the usual photocatalyst fac-Ir(ppy) $)_{3}$. Ionic and radical mechanisms afforded complementary results in terms of chemical yields, although, in general, photoredox catalysis allowed to obtain higher chemical yields. However, higher diastereoselectivity of the resulting 3,3'-bioxindoles is achieved by the DaA.

\section{Experimental Section}

General: Melting points were determined with a Marienfeld melting-point meter (MPM-H2) apparatus and are uncorrected. For flash chromatography, silica gel $60(40-60 \mu \mathrm{m})$ was employed. ${ }^{1} \mathrm{H}$ NMR $(300$, $400 \mathrm{MHz}$ ) and ${ }^{13} \mathrm{C}$ NMR (75 or $101 \mathrm{MHz}$ ) spectra were recorded with Bruker AV300, and Bruker AV400, respectively, with $\mathrm{CDCl}_{3}$ as solvent and TMS as internal standard for ${ }^{1} \mathrm{H}$ NMR spectra, and the chloroform signal for ${ }^{13} \mathrm{C}$ NMR spectra; chemical shifts are given in ppm. Lowresolution electron impact (DIP-EI) mass spectra were obtained at $70 \mathrm{eV}$ with an Agilent 6890N Network GC system and an Agilent 5973Network Mass Selective Detector. High-resolution mass spectra (DIP-EI) were recorded with a QTOF Agilent 7200 instrument for the exact mass and Agilent $7890 \mathrm{~B}$ for the GC. Analytical TLC was performed using ALUGRAM® Xtra SIL G/UV254 silica gel plates, and the spots were detected under UV light $(\lambda=254 \mathrm{~nm})$. The synthesis of known precursors $12 a,{ }^{[23 a]} 12 b,{ }^{[23 a]} 12 d,{ }^{[23 a]} 12 e,,^{[23 a, c]} 12 f^{[23 c]}$ and $12 h^{[23 c]}$ was carried out following the reported method in yields indicated in Scheme 3. Molecules $12 \mathrm{c}$ and $12 \mathrm{~g}$ were obtained using the same procedures starting from a 1 $\mathrm{mmol} \mathrm{scale}^{[23]}$ and they have not been prepared/characterized previously.

3-Acetyl-1-benzyl-3-methylindolin-2-one (12c):[23a] $167 \mathrm{mg}$ (60\%), pale yellow plates; $\mathrm{mp} 62-63{ }^{\circ} \mathrm{C}$ (n-hexane/EtOAc); $R_{\mathrm{F}} 0.45$ ( $n$-hexane/EtOAc 9:1); IR (neat) $V_{\max } 1738,1724,1611,1475,1340 \mathrm{~cm}^{-1} ;{ }^{1} \mathrm{H}$ NMR (300 $\left.\mathrm{MHz}, \mathrm{CDCl}_{3}\right) \delta$ : 7.36-7.20 (6H, m, ArH), $7.15(1 \mathrm{H}, \mathrm{dd}, J=7.7,1.1 \mathrm{~Hz}$, $\operatorname{ArH}), 7.05(1 \mathrm{H}, \mathrm{td}, J=7.5,1.0 \mathrm{~Hz}, \operatorname{ArH}), 6.84(1 \mathrm{H}, \mathrm{d}, J=7.7 \mathrm{~Hz}, \operatorname{ArH})$, 5.05, $4.90\left(2 \mathrm{H}, 2 x d, J=15.4 \mathrm{~Hz}, \mathrm{CH}_{2}\right), 1.98\left(3 \mathrm{H}, \mathrm{s}, \mathrm{CH}_{3}\right), 1.63(3 \mathrm{H}, \mathrm{s}$, $\left.\mathrm{CH}_{3}\right) ;{ }^{13} \mathrm{C}$ NMR (75 MHz, $\mathrm{CDCl}_{3}$ ) $\delta: 200.9,176.0$ (2xCO), 143.0, 135.7, 129.6, 129.2, 129.0, 128.0, 127.6, 123.7, 123.4, 109.7 ( $\mathrm{ArC}), 62.0$ (CCO), $44.2\left(\mathrm{NCH}_{2}\right), 26.2\left(\mathrm{CCH}_{2}\right), 19.2\left(\mathrm{CH}_{3}\right) ; \mathrm{MS}(\mathrm{EI}) \mathrm{m} / \mathrm{z}: 280\left(\mathrm{M}^{+}+1,1 \%\right), 279$ $\left(\mathrm{M}^{+}, 10\right), 237$ (54), 147 (17), 91 (100); HRMS (ESI): calcd. for $\mathrm{C}_{18} \mathrm{H}_{17} \mathrm{NO}_{2}$ : 279.1259; found: 279.1255 .

3-Acetyl-3-allyl-1-benzylindolin-2-one (12g):[23a] $177 \mathrm{mg}$ (58\%), pale yellow oil; $R_{\mathrm{F}} 0.55$ ( $n$-hexane/EtOAc 9:1); IR (neat) $V_{\max } 3050,2966,1735$, 1722, 1621, 1474, $1340 \mathrm{~cm}^{-1}$; ${ }^{1} \mathrm{H}$ NMR (400 MHz, CDCl $) \delta 7.37-6.99$ $(7 \mathrm{H}, \mathrm{m}, \mathrm{ArH}), 6.80(2 \mathrm{H}, \mathrm{d}, J=7.8 \mathrm{~Hz}, \mathrm{ArH}), 5.39-5.24\left(1 \mathrm{H}, \mathrm{m}, \mathrm{CH}=\mathrm{CH}_{2}\right)$, 5.14-4.75 $\left(4 \mathrm{H}, \mathrm{m}, \mathrm{CH}=\mathrm{CH}_{2}\right.$, and $\left.\mathrm{NCH}_{2}\right), 3.05-2.89\left(2 \mathrm{H}, \mathrm{m}, \mathrm{C}=\mathrm{CCH}_{2}\right)$, $2.00\left(3 \mathrm{H}, \mathrm{s}, \mathrm{CH}_{3}\right) ;{ }^{13} \mathrm{C} \mathrm{NMR}\left(101 \mathrm{MHz}, \mathrm{CDCl}_{3}\right) \delta: 200.5,174.6(2 \times \mathrm{CO})$, $143.4, \quad 135.5, \quad 131.5, \quad 128.8, \quad 128.7, \quad 127.9, \quad 127.3,126.9,124.1$, 123.2,119.7, $109.6\left(\mathrm{ArC}\right.$ and $\left.\mathrm{CH}=\mathrm{CH}_{2}\right), 66.4(\mathrm{CCO}), 44.2\left(\mathrm{NCH}_{2}\right), 37.5$ $\left(\mathrm{CCH}_{2}\right), 26.6\left(\mathrm{CH}_{3}\right)$; MS (EI) $\mathrm{m} / \mathrm{z}: 306\left(\mathrm{M}^{+}+1,3 \%\right), 305\left(\mathrm{M}^{+}, 13\right), 263(44)$, 223 (27), 173 (15), 91 (100); HRMS (ESI): calcd. for $\mathrm{C}_{20} \mathrm{H}_{19} \mathrm{NO}_{2}$ : 305.1416; found: 305.1420 .

General procedure for the synthesis of 3-bomooxindoles (13): Initially, two solutions were prepared independently. Solution a): under $\mathrm{Ar}$ atmosphere, $N$-bromosuccinimide ( 1.1 equiv, $0.33 \mathrm{mmol}, 58.7 \mathrm{mg}$ ) was dissolved in $1.5 \mathrm{~mL}$ of anhydrous THF. This solution was protected from light. Solution $b$ ): to a solution of the 3-acetyllindolin-2-one derivative 12 ( 1 equiv, $0.3 \mathrm{mmol}$ ) in $1.5 \mathrm{~mL}$ of anhydrous THF (under Ar atmosphere), $1 \mathrm{M}$ lithium ethoxide in THF (1 eq., $0.3 \mathrm{mmol}, 0.3 \mathrm{~mL}$ ) was added dropwise at room temperature and stirred for $15 \mathrm{~min}$. Solution b) was added over solution a) slowly $(0.6 \mathrm{~mL} / \mathrm{min})$. Stirring was continued fro $15-$ $20 \mathrm{~min}$ at room temperature. Water $(10 \mathrm{~mL})$ was added and the mixture was extracted with ethyl acetate $(3 \times 10 \mathrm{~mL})$ and the combined organic layers were washed $\left(5 \times 10 \mathrm{~mL} \mathrm{H}_{2} \mathrm{O}\right)$ and brine, dried $\left(\mathrm{MgSO}_{4}\right)$ and Finally, 
concentrated under vacuo (15 Torr), and the residue was purified by column chromatography ( $n$-hexane/ EtOAc) obtaining pure bromides 13.

\begin{abstract}
3-Bromo-1,3-dimethylindolin-2-one (13a):[25] $51 \mathrm{mg}(70 \%)$, pale yellow prisms; mp 83-85 ${ }^{\circ} \mathrm{C}$ ( $n$-hexane/EtOAc); RF 0.25 ( $n$-hexane/EtOAc 9:1); IR (neat) $V_{\max } 1719,1611,1470,1345,749,663 \mathrm{~cm}^{-1} ;{ }^{1} \mathrm{H} \mathrm{NMR}(300 \mathrm{MHz}$ $\left.\mathrm{CDCl}_{3}\right)$ ס: $7.44(1 \mathrm{H}, \mathrm{dd}, J=7.5,1.1 \mathrm{~Hz}, \mathrm{ArH}), 7.33(1 \mathrm{H}, \mathrm{td}, J=7.8,1.3$ $\mathrm{Hz}, \mathrm{ArH}), 7.12(1 \mathrm{H}, \mathrm{td}, J=7.6,0.9 \mathrm{~Hz}, \operatorname{ArH}), 6.84(1 \mathrm{H}, \mathrm{d}, J=7.8 \mathrm{~Hz}, \operatorname{ArH})$ $3.24\left(3 \mathrm{H}, \mathrm{s}, \mathrm{NCH}_{3}\right), 2.03\left(3 \mathrm{H}, \mathrm{s}, \mathrm{CCH}_{3}\right) ;{ }^{13} \mathrm{C} \mathrm{NMR}\left(101 \mathrm{MHz}, \mathrm{CDCl}_{3}\right) \delta$ : 174.8 (CO), 141.9, 131.7, 130.2, 124.2, 123.4, $108.87(\operatorname{ArC}), 52.53$ (CMe), $26.82\left(\mathrm{NCH}_{3}\right), 26.46\left(\mathrm{CCH}_{3}\right) ; \mathrm{MS}(\mathrm{EI}) \mathrm{m} / \mathrm{z}: 240\left(\mathrm{M}^{+}, 10 \%\right), 238$ $\left(\mathrm{M}^{+}, 10 \%\right) 161$ (13), $160(30), 159(41), 158$ (11), $146(10), 131$ (17), 130 (42), 118 (12), 71 (14), 70 (22), 61 (15), 57 (14), 45 (13), 43 (100); HRMS (ESI): calcd. for $\mathrm{C}_{10} \mathrm{H}_{10} \mathrm{BrNO}$ : 238.9946; found: 238.9950 .
\end{abstract}

3-Bromo-5-methoxy-1,3-dimethylindolin-2-one (13b):[25] $53 \mathrm{mg}(65 \%)$, brown needles; mp 107-108 ${ }^{\circ} \mathrm{C}$ ( $n$-hexane/EtOAc); RF 0.25 ( $n$ hexane/EtOAc 8.5:1.5); IR (neat) $\mathrm{V}_{\max } 1717,1497,1265,1109,1036,732$ $702 \mathrm{~cm}^{-1} ;{ }^{1} \mathrm{H}$ NMR $\left(300 \mathrm{MHz}, \mathrm{CDCl}_{3}\right) \delta: 7.04(1 \mathrm{H}, \mathrm{d}, J=2.5 \mathrm{~Hz}, \mathrm{ArH})$, $6.86(1 \mathrm{H}, \mathrm{dd}, J=8.5,2.6 \mathrm{~Hz}, \operatorname{Ar} H), 6.74(1 \mathrm{H}, \mathrm{d}, J=8.5 \mathrm{~Hz}, \operatorname{Ar} H), 3.82$ $\left(3 \mathrm{H}, \mathrm{s}, \mathrm{OCH}_{3}\right), 3.22\left(3 \mathrm{H}, \mathrm{s}, \mathrm{NCH}_{3}\right), 2.02\left(3 \mathrm{H}, \mathrm{s}, \mathrm{CCH}_{3}\right) ;{ }^{13} \mathrm{C} \mathrm{NMR}(75$ $\left.\mathrm{MHz}, \mathrm{CDCl}_{3}\right) \delta: 174.6(\mathrm{CO}), 156.6,135.2,132.8,114.9,111.2,109.4$ $(\mathrm{ArC}), 56.0\left(\mathrm{OCH}_{3}\right), 52.9(\mathrm{CMe}), 26.9\left(\mathrm{NCH}_{3}\right), 26.5\left(\mathrm{CCH}_{3}\right) ; \mathrm{MS}(\mathrm{EI}) \mathrm{m} / \mathrm{z}$ : $271\left(\mathrm{M}^{+}, 4 \%\right), 269\left(\mathrm{M}^{+}, 4 \%\right), 191(48), 190(100), 189(71), 176(44), 175$ (26), 174 (96), 148 (21), 146 (16), 118 (17), 117 (12), 90 (11), 43 (22); HRMS (ESI): calcd. for $\mathrm{C}_{11} \mathrm{H}_{12} \mathrm{BrNO}_{2}$ : 269.0051; found: 269.0053 .

1-Benzyl-3-bromo-3-methylindolin-2-one (13c): $49 \mathrm{mg}$ (52\%), orange wax; $R_{\mathrm{F}} 0.25$ ( $n$-hexane/EtOAc 9.5:0.5); IR (neat) $\mathrm{V}_{\max } 2359,1720,1610$, 1486, 1468, 1356, 1182, $751 \mathrm{~cm}^{-1} ;{ }^{1} \mathrm{H}$ NMR $\left(400 \mathrm{MHz}, \mathrm{CDCl}_{3}\right) \delta: 7.45$ $(1 \mathrm{H}, \mathrm{d}, J=8.2 \mathrm{~Hz}, \mathrm{ArH}), 7.34-7.25(5 \mathrm{H}, \mathrm{m}, \mathrm{ArH}), 7.19(1 \mathrm{H}, \mathrm{t}, J=7.8 \mathrm{~Hz}$, ArH), $7.07(1 \mathrm{H}, \mathrm{t}, J=8.0 \mathrm{~Hz}, \mathrm{ArH}), 6.69(1 \mathrm{H}, \mathrm{d}, J=7.8 \mathrm{~Hz}, \mathrm{ArH}), 5.02$, $4.84\left(2 \mathrm{H}, 2 \times d, J=15.7 \mathrm{~Hz}, \mathrm{NCH}_{2}\right), 2.09\left(3 \mathrm{H}, \mathrm{s}, \mathrm{CH}_{3}\right) ;{ }^{13} \mathrm{C} \mathrm{NMR}(101 \mathrm{MHz}$ $\left.\mathrm{CDCl}_{3}\right)$ ס: 175.10 (CO), 141.0, 135.3, 131.8, 130.1, 129.1, 129.0, 127.9, 127.3, 127.2, 124.3, 123.5, 109.9 ( $\operatorname{ArC}), 52.6(\mathrm{CMe}), 44.1\left(\mathrm{CH}_{2}\right), 26.4$ $\left(\mathrm{CH}_{3}\right)$; MS (El) m/z: $317\left(\mathrm{M}^{+}, 1 \%\right), 315\left(\mathrm{M}^{+}, 1 \%\right), 237(33), 236(34), 235$ (49), 91 (100); HRMS (ESI): calcd. for $\mathrm{C}_{16} \mathrm{H}_{14} \mathrm{BrNO}$ : 315.0259; found: 315.0257 .

1-Benzyl-3-bromo-5-methoxy-3-methylindolin-2-one (13d): $47 \mathrm{mg}$ (45\%), brown wax; RF 0.25 ( $n$-hexane/EtOAc 9:1); IR (neat) $V_{\max } 1720,1495$ $1264,1041,895,732,702 \mathrm{~cm}^{-1} ;{ }^{1} \mathrm{H}$ NMR $\left(300 \mathrm{MHz}, \mathrm{CDCl}_{3}\right)$ ס: 7.34-7.25 $(5 \mathrm{H}, \mathrm{m}, \mathrm{ArH}), 7.04(1 \mathrm{H}, \mathrm{d}, J=2.6 \mathrm{~Hz}, \mathrm{ArH}), 6.72(1 \mathrm{H}, \mathrm{dd}, J=8.6,2.6 \mathrm{~Hz}$, $\mathrm{ArH}), 6.58(1 \mathrm{H}, \mathrm{ArH}), 5.00,4.81\left(2 \mathrm{H}, 2 \times \mathrm{xd}, J=15.8 \mathrm{~Hz}, \mathrm{CH}_{2}\right), 3.77(3 \mathrm{H}, \mathrm{s}$, $\left.\mathrm{OCH}_{3}\right), 2.08\left(3 \mathrm{H}, \mathrm{s}, \mathrm{CH}_{3}\right) ;{ }^{13} \mathrm{C} \mathrm{NMR}\left(101 \mathrm{MHz}, \mathrm{CDCl}_{3}\right)$ ठ: 174.9 (CO), $156.6,135.4,134.3,132.9,129.0,128.9,127.9,127.2,127.2,114.9$ 111.1, $110.5(\mathrm{ArC}), 55.9\left(\mathrm{OCH}_{3}\right), 52.9(\mathrm{CMe}), 44.2\left(\mathrm{CH}_{2}\right), 26.5\left(\mathrm{CH}_{3}\right) ; \mathrm{MS}$ (EI) $m / z$ : $347\left(\mathrm{M}^{+}, 1 \%\right), 345\left(\mathrm{M}^{+}, 1 \%\right), 267$ (27), 266 (31), 265 (97), 146 (14), 91 (100); HRMS (ESI): calcd. for $\mathrm{C}_{17} \mathrm{H}_{16} \mathrm{BrNO}_{2}$ : 345.0364; found: 345.0356

3-Allyl-3-bromo-1-methylindolin-2-one (13e): ${ }^{[31]} 36 \mathrm{mg}(45 \%)$, pale yellow prisms; mp $76-77{ }^{\circ} \mathrm{C}$ ( $n$-hexane/EtOAc); $R_{\mathrm{F}} 0.25$ ( $n$-hexane/EtOAc 9:1); IR (neat) $V_{\max } 1723,1612,1471,1265,930,732,702 \mathrm{~cm}^{-1} ;{ }^{1} \mathrm{H}$ NMR $(300$ $\left.\mathrm{MHz}, \mathrm{CDCl}_{3}\right)$ d: $7.42(1 \mathrm{H}, \mathrm{dd}, J=7.5,1.2 \mathrm{~Hz}, \mathrm{ArH}), 7.33(1 \mathrm{H}, \mathrm{td}, J=7.8$, $1.3 \mathrm{~Hz}, \operatorname{ArH}), 7.10(1 \mathrm{H}, \mathrm{td}, J=7.6,1.0 \mathrm{~Hz}, \operatorname{ArH}), 6.83(1 \mathrm{H}, \mathrm{d}, J=7.8 \mathrm{~Hz}$, $\mathrm{ArH}), 5.60-5.44\left(1 \mathrm{H}, \mathrm{m}, \mathrm{HC}=\mathrm{CH}_{2}\right), 5.17-5.03\left(2 \mathrm{H}, \mathrm{m}, \mathrm{HC}=\mathrm{CH}_{2}\right), 3.23(3 \mathrm{H}$ $\left.\mathrm{s}, \mathrm{NCH}_{3}\right), 3.18-2.97\left(2 \mathrm{H}, \mathrm{m}, \mathrm{CH}_{2}\right) ;{ }^{13} \mathrm{C} \mathrm{NMR}\left(101 \mathrm{MHz}, \mathrm{CDCl}_{3}\right) \delta: 173.9$ (CO), 142.5, 131.1, 130.2, 129.7, 125.0, 123.4, 120.8, 108.8 ( $\operatorname{ArC}$ and $\left.\mathrm{CH}=\mathrm{CH}_{2}\right), 55.1(\mathrm{CBr}), 43.5\left(\mathrm{CH}_{2}\right), 26.8\left(\mathrm{NCH}_{3}\right) ; \mathrm{MS}(\mathrm{EI}) \mathrm{m} / \mathrm{z}: 267\left(\mathrm{M}^{+}\right.$, 2\%), $265\left(\mathrm{M}^{+}, 3 \%\right), 187$ (12), 186 (19), 185 (33), 184 (32), 158 (12), 146 (24), 71 (10), 70 (18), 61 (17), 57 (13),45 (15), 43 (100); HRMS (ESI): calcd. for $\mathrm{C}_{12} \mathrm{H}_{12} \mathrm{BrNO}$ : 265.0102; found: 265.0115 .
3-Allyl-3-bromo-5-methoxy-1-methylindolin-2-one (13f): $53 \mathrm{mg}$ (60\%), yellow wax; $R_{\mathrm{F}} 0.25$ ( $n$-hexane/EtOAc 9:1); IR (neat) $V_{\max } 1719,1496$ 1288, 1265, 1034, 733, $702 \mathrm{~cm}^{-1}$; ${ }^{1} \mathrm{H}$ NMR $\left(300 \mathrm{MHz}, \mathrm{CDCl}_{3}\right)$ ס: $7.02(1 \mathrm{H}$, d, $J=2.5 \mathrm{~Hz}, \operatorname{Ar} H), 6.86(1 \mathrm{H}, \mathrm{dd}, J=8.5,2.6 \mathrm{~Hz}, \operatorname{Ar} H), 6.73(1 \mathrm{H}, \mathrm{d}, J=$ $8.5 \mathrm{~Hz}, \mathrm{Ar} H), 5.64-5.44\left(1 \mathrm{H}, \mathrm{m}, \mathrm{HC}=\mathrm{CH}_{2}\right), 5.17-5.03\left(2 \mathrm{H}, \mathrm{m}, \mathrm{HC}=\mathrm{CH}_{2}\right)$, $3.81\left(3 \mathrm{H}, \mathrm{s}, \mathrm{OCH}_{3}\right), 3.20\left(3 \mathrm{H}, \mathrm{s}, \mathrm{NCH}_{3}\right), 3.06\left(2 \mathrm{H}, \mathrm{m}, \mathrm{CH}_{2}\right) ;{ }^{13} \mathrm{C} \mathrm{NMR}(101$ $\left.\mathrm{MHz}, \mathrm{CDCl}_{3}\right)$ ס: 174.0 (CO), 156.8, 136.2, 131.3, 131.1, 121.2, 115.1, 112.3, 109.6 ( $\mathrm{ArC}$ and $\left.\mathrm{CH}=\mathrm{CH}_{2}\right), 56.3\left(\mathrm{OCH}_{3}\right), 55.7(\mathrm{CBr}), 43.8\left(\mathrm{CH}_{2}\right)$, $27.2\left(\mathrm{NCH}_{3}\right)$; MS (EI) m/z: $297\left(\mathrm{M}^{+}, 4 \%\right), 295\left(\mathrm{M}^{+}, 4 \%\right), 217(46), 216$ (52), 215 (100), 214 (20), 200 (36), 188 (11), 184 (11), 176 (75), 174 (17), 173 (11), 172 (40), 144 (14), 115 (40), 43 (45); HRMS (ESI): calcd. for $\mathrm{C}_{13} \mathrm{H}_{14} \mathrm{BrNO}_{2}$ : 295.0208; found: 295.0214 .

3-Allyl-1-benzyl-3-bromoindolin-2-one (13g)::[26] $52 \mathrm{mg}$ (51\%), orange wax; $R_{F} 0.25$ ( $n$-hexane/EtOAc 9.7:0.3); IR (neat) $v_{\max } 2362,1721,1610$ 1486, $1468,1355,1174,927,749 \mathrm{~cm}^{-1} ;{ }^{1} \mathrm{H}$ NMR $\left(400 \mathrm{MHz}, \mathrm{CDCl}_{3}\right) \delta$ : 7.45-7.41 $(1 \mathrm{H}, \mathrm{m}, \mathrm{ArH}), 7.33-7.24(5 \mathrm{H}, \mathrm{m}, \mathrm{ArH}), 7.19(1 \mathrm{H}, \mathrm{td}, J=7.8$ $1.3 \mathrm{~Hz}, \operatorname{ArH}), 7.06(1 \mathrm{H}, \mathrm{td}, J=7.6,0.9 \mathrm{~Hz}, \operatorname{ArH}), 6.67(1 \mathrm{H}, \mathrm{d}, J=7.8 \mathrm{~Hz}$, ArH $)$, 5.59-5.45 $\left(1 \mathrm{H}, \mathrm{m}, \mathrm{HC}=\mathrm{CH}_{2}\right), 5.20-5.05\left(2 \mathrm{H}, \mathrm{m}, \mathrm{HC}=\mathrm{CH}_{2}\right), 4.97$ $4.88\left(2 \mathrm{H}, 2 \mathrm{xd}, J=15.8 \mathrm{~Hz}, \mathrm{NCH}_{2}\right), 3.26-3.09\left(2 \mathrm{H}, \mathrm{m}, \mathrm{BrCCH}_{2}\right) ;{ }^{13} \mathrm{C} \mathrm{NMR}$ $\left(101 \mathrm{MHz}, \mathrm{CDCl}_{3}\right) \delta 174.1$ (CO), 141.6, 135.2, 131.1, 130.1, 129.6, 128.9, $128.8,127.9,127.3,127.2,124.9,123.4,121.1,109.9(\operatorname{ArC}$ and $\left.\mathrm{CH}=\mathrm{CH}_{2}\right), 55.1(\mathrm{CBr}), 44.2,43.2\left(2 \times \mathrm{CH}_{2}\right) ; \mathrm{MS}(\mathrm{EI}) \mathrm{m} / \mathrm{z}: 343\left(\mathrm{M}^{+}, 2 \%\right)$, $341\left(\mathrm{M}^{+}, 2 \%\right), 263$ (34), 262 (28), 261 (48), 232 (15), 222 (40), 218 (13), 91 (100); HRMS (ESI): calcd. for $\mathrm{C}_{18} \mathrm{H}_{16} \mathrm{BrNO}$ : 341.0415; found: 341.0415.

3-Allyl-1-benzyl-3-bromo-5-methoxyindolin-2-one (13h): $93 \mathrm{mg},(83 \%)$, yellow oil; RF 0.25 ( $n$-hexane/EtOAc 9:1); IR (neat) $V_{\max } 1717,1492,1435$, $1178,1042,733,695 \mathrm{~cm}^{-1} ;{ }^{1} \mathrm{H}$ NMR $\left(300 \mathrm{MHz}, \mathrm{CDCl}_{3}\right)$ 8: 7.33-7.24 (5H, $\mathrm{m}, \operatorname{ArH}), 7.02(1 \mathrm{H}, \mathrm{d}, J=2.5 \mathrm{~Hz}, \mathrm{ArH}), 6.71(1 \mathrm{H}, \mathrm{dd}, J=8.6,2.6 \mathrm{~Hz}, \mathrm{ArH})$, $6.55(1 \mathrm{H}, \mathrm{d}, J=8.6 \mathrm{~Hz}, \operatorname{ArH}), 5.62-5.43\left(1 \mathrm{H}, \mathrm{m}, H \mathrm{HC}=\mathrm{CH}_{2}\right), 5.23-5.04$ $\left(2 \mathrm{H}, \mathrm{m}, \mathrm{HC}=\mathrm{CH}_{2}\right), 4.94,4.85\left(2 \mathrm{H}, 2 \mathrm{xd}, J=15.8 \mathrm{~Hz}, \mathrm{NCH}_{2}\right), 3.76(3 \mathrm{H}, \mathrm{s}$, $\left.\mathrm{OCH}_{3}\right), 3.22-3.10\left(2 \mathrm{H}, \mathrm{m}, \mathrm{BrCCH}_{2}\right) ;{ }^{13} \mathrm{C} \mathrm{NMR}\left(101 \mathrm{MHz}, \mathrm{CDCl}_{3}\right)$ ठ: 173.8 (CO), 156.4, 135.3, 134.9, 131.1, 130.7, 128.9, 128.8, 127.8, 127.3, 127.2, 121.1, 114.8, 111.8, 110.4 ( $\mathrm{ArC}$ and $\left.\mathrm{CH}=\mathrm{CH}_{2}\right), 55.9\left(\mathrm{OCH}_{3}\right), 55.4$ (CBr), 44.2, $43.5\left(2 \times \mathrm{CH}_{2}\right)$; MS (EI) m/z: $373\left(\mathrm{M}^{+}, 1 \%\right), 371\left(\mathrm{M}^{+}, 1 \%\right), 292$ (23), 291 (100), 200 (14), 172 (15), 91 (64); HRMS (ESI): calcd. for $\mathrm{C}_{19} \mathrm{H}_{18} \mathrm{BrNO}_{2}$ : 371.0521 ; found: 371.0529.

General procedure for the synthesis of 3,3'-bioxindoles (11) METHOD A: In a Schlenk tube containing 3-acetyllindolin-2-one derivative (12) $(0.3 \mathrm{mmol})$ dissolved in anhydrous THF $(3 \mathrm{~mL})$, lithium ethoxide ( $1 \mathrm{M}$ solution in THF) ( 1 equiv, $0.3 \mathrm{mmol}, 0.3 \mathrm{~mL}$ ) was added dropwise under $\mathrm{Ar}$ atmosphere. Then, $\mathrm{N}$-iodosuccinimide ( 0.5 equiv, 0.15 $\mathrm{mmol}, 33 \mathrm{mg}$ ) was added, and the reaction was stirred 15-20 minutes at room temperature. Water $(10 \mathrm{~mL})$ was added, the mixture was extracted with EtOAc $(3 \times 10 \mathrm{~mL})$ and the combined organic layers were washed $\left(5 \times 10 \mathrm{~mL} \mathrm{H} \mathrm{H}_{2} \mathrm{O}\right)$ and brine, dried $\left(\mathrm{MgSO}_{4}\right)$ and evaporated under vacuo (15 Torr) and the residue was purified by column chromatography ( $n$ hexane/ EtOAc). METHOD B: A Schlenk tube containing a solution of 3bromolindolin-2-one derivative $(0.3 \mathrm{mmol})$, photocatalyst $23(1 \mathrm{mg}, 0.5$ $\mathrm{mol} \%)$ and freshly distilled anhydrous DIPEA $(0.078 \mathrm{~mL}, 1.5$ equiv, 0.45 $\mathrm{mmol})$ in THF ( $3 \mathrm{~mL}$ ) was degassed by freezing-pump ( 3 cycles). Then, the reaction was irradiated with blue LEDs for $15 \mathrm{~h}$ at room temperature. Water $(10 \mathrm{~mL})$ was added, and the mixture was extracted with EtOAc $(3 \times 10 \mathrm{~mL})$ and the combined organic layers were dried $\left(\mathrm{MgSO}_{4}\right)$, concentrated under vacuo and the residue was purified by column chromatography ( $n$-hexane/ EtOAc).

1,1'3,3'-Tetramethyl-[3,3'-biindoline]-2,2'-dione (11a):[24] $44 \mathrm{mg}$ (90\%, Method A), $35 \mathrm{mg}\left(72 \%\right.$ Method B); $\left(R^{*}, R^{*}\right)$ : pale yellow plates; $\mathrm{mp} 166-$ $167{ }^{\circ} \mathrm{C}$ ( $n$-hexane/EtOAC); RF 0.70 ( $n$-hexane/EtOAc 5:5); IR (neat) $V_{\max }$ 2925, 1697, 1609, 1348, 1096, 740, $695 \mathrm{~cm}^{-1} ;{ }^{1} \mathrm{H}$ NMR $\left(300 \mathrm{MHz}, \mathrm{CDCl}_{3}\right)$ ס: 7.08-6.97 (4H, m, ArH), $6.82(2 \mathrm{H}, \mathrm{t}, J=7.6 \mathrm{~Hz}, \operatorname{Ar} H), 6.45(2 \mathrm{H}, \mathrm{d}, J=$ 
$7.7 \mathrm{~Hz}, \mathrm{ArH}), 3.09\left(6 \mathrm{H}, \mathrm{s}, 2 \times \mathrm{NCH}_{3}\right), 1.75\left(6 \mathrm{H}, \mathrm{s}, 2 \times \mathrm{CH}_{3}\right) ;{ }^{13} \mathrm{C} \mathrm{NMR}(75$ $\left.\mathrm{MHz}, \mathrm{CDCl}_{3}\right)$ ס: 178.3 (2xCO), $142.7(2 \times \mathrm{C}), 131.2,128.2,122.9,121.9$, 107.5 ( $\mathrm{ArC}), 51.3(2 \times \mathrm{C}), 25.8\left(2 \times \mathrm{NCH}_{3}\right), 16.2\left(2 \times \mathrm{CH}_{3}\right) ; \mathrm{MS}(\mathrm{EI}) \mathrm{m} / \mathrm{z}: 320$ $\left(\mathrm{M}^{+}, 19 \%\right) 161$ (61), 160 (100), 130 (12), 117 (13); HRMS (ESI): calcd. for $\mathrm{C}_{20} \mathrm{H}_{20} \mathrm{~N}_{2} \mathrm{O}_{2}$ : 320.1529; found 320.1534. Meso: pale yellow oil; $R_{\mathrm{F}}$ 0.30 ( $n$-hexane/EtOAc 5:5); IR (neat) $V_{\max } 1967,1607,1374,1347,1094$, 1026, 757, $736 \mathrm{~cm}^{-1} ;{ }^{1} \mathrm{H} \mathrm{NMR}\left(300 \mathrm{MHz}, \mathrm{CDCl}_{3}\right) \delta: 7.24(2 \mathrm{H}, \mathrm{t}, J=7.7 \mathrm{~Hz}$ $\operatorname{ArH}), 6.86(2 \mathrm{H}, \mathrm{t}, J=7.6 \mathrm{~Hz}, \operatorname{Ar} H), 6.72(2 \mathrm{H}, \mathrm{d}, J=7.8 \mathrm{~Hz}, \operatorname{Ar} H), 6.61$ $(2 \mathrm{H}, \mathrm{d}, J=7.3 \mathrm{~Hz}, \mathrm{ArH}), 2.97\left(6 \mathrm{H}, \mathrm{s}, \mathrm{NCH}_{3}\right), 1.67\left(6 \mathrm{H}, \mathrm{s}, \mathrm{CH}_{3}\right) ;{ }^{13} \mathrm{C} \mathrm{NMR}$

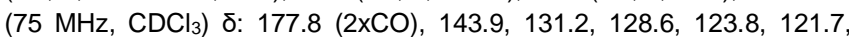
$108.0(\mathrm{ArC}), 51.8(2 \times \mathrm{C}), 26.0\left(2 \times \mathrm{NCH}_{3}\right), 17.5\left(2 \times \mathrm{CH}_{3}\right) ; \mathrm{MS}(\mathrm{El}) \mathrm{m} / \mathrm{z}: 320$ $\left(\mathrm{M}^{+}, 8 \%\right), 194$ (4), 161 (28), 160 (100), 145 (3), $132(5), 130$ (6), 117 (7), 77 (3); HRMS (ESI): calcd. for $\mathrm{C}_{20} \mathrm{H}_{20} \mathrm{~N}_{2} \mathrm{O}_{2}$ : 320.1525 ; found 320.1533 .

5,5'-Dimethoxy-1, 1',3,3'-tetramethyl-[3,3'-biindoline]-2,2'-dione (11b). ${ }^{[24]}$ $29 \mathrm{mg}\left(51 \%\right.$, Method A), $31 \mathrm{mg}(54 \%$ Method $\mathrm{B}) ;\left(R^{\star}, R^{*}\right)$ : pale orange solid; mp 213-214 ${ }^{\circ} \mathrm{C}$ ( $n$-hexane/EtOAc); $R \mathrm{~F} \quad 0.8$ ( $n$-hexane/EtOAc 4.5:5.5); IR (neat) $\mathrm{V}_{\max } 2940,1686,1493,1215,1039,802 \mathrm{~cm}^{-1} ;{ }^{1} \mathrm{H}$ NMR $\left(300 \mathrm{MHz}, \mathrm{CDCl}_{3}\right) \delta: 6.73(2 \mathrm{H}, \mathrm{d}, J=2.5 \mathrm{~Hz}, \mathrm{ArH}), 6.58(2 \mathrm{H}, \mathrm{dd}, J=8.5$, $2.6 \mathrm{~Hz}, \mathrm{ArH}), 6.39(2 \mathrm{H}, \mathrm{d}, J=8.5 \mathrm{~Hz}, \mathrm{ArH}), 3.69\left(6 \mathrm{H}, \mathrm{s}, 2 \times \mathrm{OCH}_{3}\right), 3.10$ $\left(6 \mathrm{H}, \mathrm{s}, 2 \times \mathrm{NCH}_{3}\right), 1.74\left(6 \mathrm{H}, \mathrm{s}, 2 \times \mathrm{CCH}_{3}\right) ;{ }^{13} \mathrm{C}$ NMR $\left(75 \mathrm{MHz}, \mathrm{CDCl}_{3}\right) \delta$ : $177.9(2 \times C O), 155.7,136.1,132.6,113.1,110.2,107.8(\mathrm{ArH}), 55.9$ $\left(2 \times \mathrm{OCH}_{3}\right), 51.5(2 \times \mathrm{C}), 26.0\left(2 \times \mathrm{NCH}_{3}\right), 16.6\left(2 \times \mathrm{CH}_{3}\right) ; \mathrm{MS}(\mathrm{EI}) \mathrm{m} / \mathrm{z}: 380$ $\left(\mathrm{M}^{+}, 10 \%\right), 192$ (2), 191 (16), 190 (100), 176 (2), 175 (6), 174 (3), $162(2)$, 160 (2), 159 (2), 147 (5), 119 (2), 118 (3); HRMS (ESI): calcd. for $\mathrm{C}_{22} \mathrm{H}_{24} \mathrm{~N}_{2} \mathrm{O}_{4}$ : 380.1736 ; found 380.1749 . Meso: pale yellow oil; $R_{F} 0.30$ (n-hexane/EtOAc 4.5:5.5); IR (neat) $V_{\max } 1701,1497,1289,1236,1035$ $732 \mathrm{~cm}^{-1} ;{ }^{1} \mathrm{H}$ NMR $\left(300 \mathrm{MHz}, \mathrm{CDCl}_{3}\right) \delta: 6.78(2 \mathrm{H}, \mathrm{d}, J=10.9 \mathrm{~Hz}, \mathrm{ArH})$, $6.63(2 \mathrm{H}, \mathrm{d}, J=8.4 \mathrm{~Hz}, \mathrm{ArH}), 6.29(2 \mathrm{H}, \mathrm{s}, \mathrm{ArH}), 3.65\left(6 \mathrm{H}, \mathrm{s}, 2 \times \mathrm{OCH}_{3}\right)$, $2.96\left(6 \mathrm{H}, \mathrm{s}, 2 \times \mathrm{NCH}_{3}\right), 1.66\left(6 \mathrm{H}, \mathrm{s}, 2 \times \mathrm{CH}_{3}\right) ;{ }^{13} \mathrm{C} \mathrm{NMR}\left(75 \mathrm{MHz}, \mathrm{CDCl}_{3}\right) \delta$ : 177.2 (2xCO), 155.2, 137.4, 132.3, 113.0, 111.2, 108.1, $55.8\left(2 \mathrm{XOCH}_{3}\right)$, $51.9(2 \times \mathrm{C}), 26.0\left(2 \times \mathrm{NCH}_{3}\right), 17.4\left(2 \times \mathrm{CH}_{3}\right) ; \mathrm{MS}(\mathrm{EI}) \mathrm{m} / \mathrm{z}: 380\left(\mathrm{M}^{+}, 10 \%\right)$, 192 (2), 191 (15), 190 (100), 176 (2), 175 (6), 174 (2), 162 (2), 160 (2), 159 (2), 147 (5), 119 (2), 118 (3); HRMS (ESI): calcd. for $\mathrm{C}_{22} \mathrm{H}_{24} \mathrm{~N}_{2} \mathrm{O}_{4}$ : 380.1736 ; found 380.1756 .

1,1'-Dibenzyl-3,3'-dimethyl-[3,3'-biindoline]-2,2'-dione (11c):[24] $34 \mathrm{mg}$ (48\%, Method A), $33 \mathrm{mg}\left(47 \%\right.$ Method B); $\left(R^{\star}, R^{\star}\right)$ : yellow solid; $\mathrm{mp} 189-$ $190{ }^{\circ} \mathrm{C}$ ( $n$-hexane/EtOAC); $R_{\mathrm{F}} 0.70$ ( $n$-hexane/EtOAc 6:4); IR (neat) $V_{\max }$ 2970, 1697, 1606, 1371, 1181, 741, $\left.694 \mathrm{~cm}^{-1} ;{ }^{1} \mathrm{H} \mathrm{NMR} \mathrm{(300} \mathrm{MHz,} \mathrm{CDCl}\right)$ ס: 7.31-7.18 (10H, m, ArH), $7.05(2 \mathrm{H}, \mathrm{d}, J=7.5 \mathrm{~Hz}, \mathrm{ArH}), 6.94(2 \mathrm{H}, \mathrm{td}, J$ $=7.7,1.2 \mathrm{~Hz}, \operatorname{ArH}), 6.66(2 \mathrm{H}, \mathrm{td}, J=7.6,1.0 \mathrm{~Hz}, \operatorname{ArH}), 6.46(1 \mathrm{H}, \mathrm{d}, J=$ $7.6 \mathrm{~Hz}, \mathrm{ArH}), 5.01,4.68\left(4 \mathrm{H}, 2 \times \mathrm{d}, J=15.6 \mathrm{~Hz}, 2 \times \mathrm{CH}_{2}\right), 1.84(6 \mathrm{H}, \mathrm{s}$, $\left.2 \times \mathrm{CH}_{3}\right) ;{ }^{13} \mathrm{C} \mathrm{NMR}\left(75 \mathrm{MHz}, \mathrm{CDCl}_{3}\right) \delta: 178.6(2 \times \mathrm{CO}), 142.0,135.8,131.5$, $128.8,128.0,127.7,127.7,123.7,122.3,108.7,50.9(2 \times C), 43.9\left(2 \times \mathrm{CH}_{2}\right)$ $17.9\left(2 \times \mathrm{CH}_{3}\right) ; \mathrm{MS}$ (EI) m/z: $472\left(\mathrm{M}^{+}, 3 \%\right), 238(6), 237(43), 236(100)$, 235 (6), 91 (61); HRMS (ESI): calcd. for $\mathrm{C}_{32} \mathrm{H}_{28} \mathrm{~N}_{2} \mathrm{O}_{2}$ : 472.2151; found 472.2169. Meso: colorless oil; $R_{\mathrm{F}} 0.50$ ( $n$-hexane/EtOAc 6:4); IR (neat) $V_{\max } 1708,1608,1487,1348,1183,731 \mathrm{~cm}^{-1} ;{ }^{1} \mathrm{H} \mathrm{NMR}\left(300 \mathrm{MHz}, \mathrm{CDCl}_{3}\right)$ ס: 7.20-7.09 (10H, m, ArH), 6.99-6.91 (4H, m, ArH), $6.81(2 \mathrm{H}, \mathrm{t}, J=7.5$ $\mathrm{Hz}, \mathrm{ArH}), 6.58(2 \mathrm{H}, \mathrm{d}, J=7.7 \mathrm{~Hz}, \mathrm{ArH}), 4.93,4.65(4 \mathrm{H}, 2 \times \mathrm{d}, J=15.9 \mathrm{~Hz}$, $\left.2 \times \mathrm{CH}_{2}\right), 1.80\left(3 \mathrm{H}, \mathrm{s}, 2 \times \mathrm{CH}_{3}\right) ;{ }^{13} \mathrm{C}$ NMR $\left(75 \mathrm{MHz}, \mathrm{CDCl}_{3}\right) \delta: 178.2(2 \times \mathrm{CO})$, 143.1, 135.9, 131.6, 128.7, 128.6, 127.3, 127.2, 124.1, 122.1, 109.4 $(\operatorname{ArC}), 51.5(2 \times C), 44.0\left(2 \times \mathrm{CH}_{2}\right), 18.8\left(2 \times \mathrm{CH}_{3}\right)$; LRMS (EI) $\mathrm{m} / \mathrm{z}: 472\left(\mathrm{M}^{+}\right.$, 3\%), 237 (38), 236 (100), 91 (58); HRMS (ESI): calcd. for $\mathrm{C}_{32} \mathrm{H}_{28} \mathrm{~N}_{2} \mathrm{O}_{2}$ : 472.2151; found 472.2169 .

1,1'-Dibenzyl-5,5'-dimethoxy-3,3'-dimethyl-[3,3'-biindoline]-2,2'-dione (11d): $37 \mathrm{mg}\left(46 \%\right.$, Method A), $24 \mathrm{mg}\left(30 \%\right.$ Method B); $\left(R^{\star}, R^{\star}\right)$ : yellow plates; mp $193-194{ }^{\circ} \mathrm{C}$ ( $n$-hexane/EtOAc); $R_{\mathrm{F}} 0.70$ ( $n$-hexane/EtOAc $6: 4$ ); IR (neat) $V_{\max } 2967,1698,1453,1180,1036,730,700 \mathrm{~cm}^{-1} ;{ }^{1} \mathrm{H}$ NMR (300 MHz, $\left.\mathrm{CDCl}_{3}\right) \delta: 7.29-7.22(6 \mathrm{H}, \mathrm{m}, \mathrm{ArH}), 7.14(4 \mathrm{H}, \mathrm{dd}, J=7.4,2.0$ $\mathrm{Hz}, \operatorname{Ar} H), 6.86(2 \mathrm{H}, \mathrm{d}, J=2.5 \mathrm{~Hz}, \operatorname{Ar} H), 6.50(2 \mathrm{H}, \mathrm{dd}, J=8.5,2.6 \mathrm{~Hz}$, $\operatorname{ArH}), 6.32(2 \mathrm{H}, \mathrm{d}, J=8.5 \mathrm{~Hz}, \mathrm{ArH}), 5.07,4.66(4 \mathrm{H}, 2 \mathrm{xd}, J=15.8 \mathrm{~Hz}, 2 \mathrm{x}$ $\left.\mathrm{CH}_{2}\right), 3.58\left(6 \mathrm{H}, \mathrm{s}, 2 \times \mathrm{OCH}_{3}\right), 1.86\left(6 \mathrm{H}, \mathrm{s}, 2 \mathrm{xCH}_{3}\right) ;{ }^{13} \mathrm{C} \mathrm{NMR}(75 \mathrm{MHz}$,
$\left.\mathrm{CDCl}_{3}\right)$ ס: $178.4(2 \times C O), 155.8,135.8,135.4,132.9,128.9,127.6,127.2$ 112.9, 110.9, $109.5(\mathrm{ArC}), 55.6\left(2 \mathrm{xOCH}_{3}\right), 51.3(2 \times \mathrm{C}), 43.8\left(2 \mathrm{xCH}_{2}\right), 18.4$ $\left(2 \times \mathrm{CH}_{3}\right) ; \mathrm{MS}$ (EI) m/z: $532\left(\mathrm{M}^{+}, 6 \%\right), 267$ (25), 266 (100), 265 (7), 91 (47); HRMS (ESI): calcd. for $\mathrm{C}_{34} \mathrm{H}_{32} \mathrm{~N}_{2} \mathrm{O}_{4}$ : 532.2362; found 532.2361. Meso: could not be isolated.

3,3'-Diallyl-1,1'-dimethyl-[3,3'-biindoline]-2,2'-dione (11e):[24] $22 \mathrm{mg}(40 \%$, Method A), $39 \mathrm{mg}\left(70 \%\right.$ Method B); $\left(R^{\star}, R^{\star}\right)$ : yellow solid; mp $215-216^{\circ} \mathrm{C}$ ( $n$-hexane/EtOAc); $R_{F} 0.70$ ( $n$-hexane/EtOAc 6:4); IR (neat) $V_{\max } 2932$, 1686, 1491, 1353, 1096, 924, $757 \mathrm{~cm}^{-1} ;{ }_{1}^{1} \mathrm{H}$ NMR $\left(300 \mathrm{MHz}, \mathrm{CDCl}_{3}\right) \delta$ 7.07-6.96 (4H, m, ArH), $6.82(2 \mathrm{H}, \mathrm{td}, J=7.6,0.9 \mathrm{~Hz}, \mathrm{ArH}), 6.41(2 \mathrm{H}, \mathrm{d}, J$ $=7.8 \mathrm{~Hz}, \mathrm{ArH}), 5.05-4.98\left(4 \mathrm{H}, \mathrm{m}, 2 \mathrm{xHC}=\mathrm{CH}_{2}\right), 4.74(2 \mathrm{H}, \mathrm{dd}, J=8.3,3.9$ $\left.\mathrm{Hz}, 2 \times H C=\mathrm{CH}_{2}\right), 3.64\left(2 \mathrm{H}, \mathrm{dd}, J=12.6,5.0 \mathrm{~Hz}, \mathrm{CH}_{2}\right), 3.06\left(6 \mathrm{H}, \mathrm{s}, \mathrm{NCH}_{3}\right)$, 3.05-2.99 (2H, m, $\left.\mathrm{CH}_{2}\right) ;{ }^{13} \mathrm{C} \mathrm{NMR}\left(75 \mathrm{MHz}, \mathrm{CDCl}_{3}\right) \delta: 177.0(2 \times \mathrm{CO})$, 143.4, 132.6, 128.3, 128.2, 123.5, 121.8, 118.9, 107.5 (ArC and $\left.\mathrm{CH}=\mathrm{CH}_{2}\right), 56.0(2 \times \mathrm{C}), 33.3\left(2 \times \mathrm{NCH}_{3}\right), 25.7\left(2 \times \mathrm{CH}_{2}\right) ; \mathrm{MS}(\mathrm{EI}) \mathrm{m} / \mathrm{z}: 372$ $\left(\mathrm{M}^{+}, 6 \%\right), 187$ (49), 186 (100), 158 (16), 144 (10), 143 (10); HRMS (ESI): calcd. for $\mathrm{C}_{24} \mathrm{H}_{24} \mathrm{~N}_{2} \mathrm{O}_{2}$ : 372.1838; found 372.1862. Meso: pale yellow oil; $R_{F} 0.30$ ( $n$-hexane/EtOAc 6:4); IR (neat) $V_{\max } 1704,1608,1469,1348$,

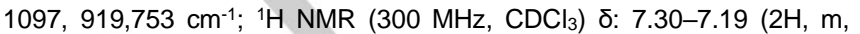
$\operatorname{Ar} H), 6.87(2 \mathrm{H}, \mathrm{t}, J=8.0 \mathrm{~Hz}, \mathrm{ArH}), 6.68(2 \mathrm{H}, \mathrm{d}, J=7.8 \mathrm{~Hz}, \mathrm{ArH}), 6.60$ $(2 \mathrm{H}, \mathrm{d}, J=7.1 \mathrm{~Hz}, \mathrm{ArH}), 5.18-5.02\left(2 \mathrm{H}, \mathrm{m}, 2 \times H C=\mathrm{CH}_{2}\right), 4.94(2 \mathrm{H}, \mathrm{dd}, J=$ 17.0, $2.3 \mathrm{~Hz}, 2 \times \mathrm{HC}=\mathrm{CHH}), 4.77(2 \mathrm{H}, \mathrm{dd}, J=9.8,2.3 \mathrm{~Hz}, 2 \times \mathrm{HC}=\mathrm{CH} H)$, $3.47\left(2 \mathrm{H}, \mathrm{dd}, J=13.1,7.2 \mathrm{~Hz}, 2 \mathrm{xCH}_{2}\right), 2.98-2.82\left(8 \mathrm{H}, \mathrm{m}, 2 \mathrm{xNCH}_{3}, 2 \mathrm{x}\right.$ $\left.\mathrm{CH}_{2}\right) ;{ }^{13} \mathrm{C} \mathrm{NMR}\left(75 \mathrm{MHz}, \mathrm{CDCl}_{3}\right) \delta: 176.2$ (2xCO), 144.7, 132.1, 128.7, 128.6, 124.3, 121.6, 119.3, 107.9 ( $\mathrm{ArC}$ and $\left.\mathrm{CH}=\mathrm{CH}_{2}\right), 56.7(2 \times \mathrm{C}), 34.9$ $\left(2 \times \mathrm{NCH}_{3}\right), 25.9\left(2 \times \mathrm{XH}_{2}\right)$; MS (EI) m/z: $372\left(\mathrm{M}^{+}, 5 \%\right), 187(45), 186(100)$, 158 (16), 144 (10), 143 (11); HRMS (ESI): calcd. for $\mathrm{C}_{24} \mathrm{H}_{24} \mathrm{~N}_{2} \mathrm{O}_{2}$ : 372.1838; found 372.1850 .

3,3'-Diallyl-5,5'-dimethoxy-1,1'-dimethyl-[3,3'-biindoline]-2,2'-dione (11f): $26 \mathrm{mg}\left(40 \%\right.$, Method A), $16 \mathrm{mg}(25 \%$ Method $\mathrm{B}) ;\left(R^{*}, R^{*}\right)$ : colorless prisms; mp 201-202 ${ }^{\circ} \mathrm{C}$ ( $n$-hexane/EtOAc); $R_{\mathrm{F}} 0.25$ ( $n$-hexane/EtOAC 9:1); IR (neat) $V_{\max } 1687,1498,1433,1235,923,811,736 \mathrm{~cm}^{-1} ;{ }^{1} \mathrm{H}$ NMR $\left(300 \mathrm{MHz}, \mathrm{CDCl}_{3}\right) \delta: 6.71(2 \mathrm{H}, \mathrm{d}, J=2.5 \mathrm{~Hz}, \mathrm{ArH}), 6.56(2 \mathrm{H}, \mathrm{dd}, J=8.4$, $2.6 \mathrm{~Hz}, \operatorname{Ar} H), 6.35(2 \mathrm{H}, \mathrm{d}, J=8.5 \mathrm{~Hz}, \operatorname{Ar} H), 5.05-4.99(2 \mathrm{H}, \mathrm{m}, 2 \mathrm{x}$ $\left.\mathrm{HC}=\mathrm{CH}_{2}\right), 4.76\left(2 \mathrm{H}, \mathrm{dd}, J=8.0,4.2 \mathrm{~Hz}, 2 \times \mathrm{HC}=\mathrm{CH}_{2}\right), 3.69(6 \mathrm{H}, \mathrm{s}, 2 \mathrm{x}$ $\left.\mathrm{OCH}_{3}\right), 3.62\left(2 \mathrm{H}, \mathrm{dd}, J=13.2,4.9 \mathrm{~Hz}, 2 \times \mathrm{CH}_{2}\right), 3.07\left(6 \mathrm{H}, \mathrm{s}, 2 \times \mathrm{NCH}_{3}\right)$, $3.01\left(2 \mathrm{H}, \mathrm{dd}, J=13.2,5.4 \mathrm{~Hz}, 2 \times \mathrm{CH}_{2}\right) ;{ }^{13} \mathrm{C}$ NMR $\left(75 \mathrm{MHz}, \mathrm{CDCl}_{3}\right) \delta$ : 176.6 (2xCO), 155.7, 137.0, 132.6, 129.7, 119.0, 113.1, 110.7, 107.7 ( $\mathrm{ArC}$ and $\left.\mathrm{CH}=\mathrm{CH}_{2}\right), 56.3(2 \times \mathrm{C}), 55.9\left(2 \times \mathrm{xOCH}_{3}\right), 33.7\left(2 \times \mathrm{CH}_{2}\right), 25.9(2 \mathrm{x}$ $\mathrm{NCH}_{3}$ ); MS (EI) m/z: $432\left(\mathrm{M}^{+}, 11 \%\right), 217$ (22), 216 (100), 174 (12); HRMS (ESI): calcd. for $\mathrm{C}_{26} \mathrm{H}_{28} \mathrm{~N}_{2} \mathrm{O}_{4}$ : 432.2049; found 432.2061. Meso: could not be isolated.

3,3'-Diallyl-1, 1'-dibenzyl-[3,3'-biindoline]-2,2'-dione (11g):[24] $20 \mathrm{mg}(26 \%$, Method A), $8 \mathrm{mg}\left(13 \%\right.$ Method B); $\left(R^{\star}, R^{\star}\right)$ : Pale yellow solid; mp 201 $202{ }^{\circ} \mathrm{C}$ ( $n$-hexane/EtOAc); $R_{\mathrm{F}} 0.70$ ( $n$-hexane/EtOAc 5:5); IR (neat) $\mathrm{V}_{\max }$ 1696, 1606, 1485, 1366, 1178, 919, 753, $695 \mathrm{~cm}^{-1} ;{ }^{1} \mathrm{H}$ NMR $(300 \mathrm{MHz}$,

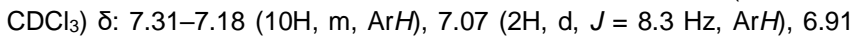
$(2 \mathrm{H}, \mathrm{td}, J=7.7,1.2 \mathrm{~Hz}, \mathrm{ArH}), 6.70(2 \mathrm{H}, \mathrm{td}, J=7.6,1.0 \mathrm{~Hz}, \mathrm{ArH}), 6.35(2 \mathrm{H}$, d, $J=7.6 \mathrm{~Hz}, \mathrm{ArH}), 5.12\left(2 \mathrm{H}, \mathrm{d}, J=15.6 \mathrm{~Hz}, 2 \times \mathrm{CH}_{2}\right), 5.08-5.01(4 \mathrm{H}, \mathrm{m}$, $\left.2 x H C=C_{2}\right), 4.85-4.75\left(2 \mathrm{H}, \mathrm{m}, 2 x H C=\mathrm{CH}_{2}\right), 4.47(2 \mathrm{H}, \mathrm{d}, J=15.6 \mathrm{~Hz}, 2 \mathrm{x}$ $\left.\mathrm{CH}_{2}\right), 3.80-3.70\left(2 \mathrm{H}, \mathrm{m}, 2 \times \mathrm{CH}_{2}\right), 3.15-3.06\left(2 \mathrm{H}, \mathrm{m}, 2 \mathrm{xCH}_{2}\right) ;{ }^{13} \mathrm{C} \mathrm{NMR}$ $\left(75 \mathrm{MHz}, \mathrm{CDCl}_{3}\right) \delta$ : 177.2 (2xCO), 142.9, 135.6, 132.6, 128.7, 128.3, $128.2,127.7,127.6,124.1,122.1,119.3,108.6\left(\mathrm{ArC}\right.$ and $\left.\mathrm{CH}=\mathrm{CH}_{2}\right)$, $55.84(2 \times \mathrm{C}), 43.9\left(2 \times \mathrm{NCH}_{2}\right), 34.2\left(2 \times \mathrm{CCH}_{2}\right) ; \mathrm{MS}(\mathrm{EI}) \mathrm{m} / \mathrm{z} 524\left(\mathrm{M}^{+}, 2 \%\right)$, 263 (54), 262 (83), 261 (4), 91 (100); HRMS (ESI): calcd. for $\mathrm{C}_{36} \mathrm{H}_{32} \mathrm{~N}_{2} \mathrm{O}_{2}$ : 524.2464; found 524.2470. Meso: could not be isolated.

3,3'-Diallyl-1,1'-dibenzyl-5,5'-dimethoxy-[3,3'-biindoline]-2,2'-dione (11h): $36 \mathrm{mg}\left(40 \%\right.$, Method A), $18 \mathrm{mg}(20 \%$ Method $\mathrm{B}) ;\left(R^{*}, R^{*}\right)$ : red plates; $\mathrm{mp}$ $152-153^{\circ} \mathrm{C}$ ( $n$-hexane/EtOAc); RF 0.70 ( $n$-hexane/EtOAc 5:5); IR (neat) $V_{\max } 1697,1494,1434,1198,1043,906,727 \mathrm{~cm}^{-1} ;{ }^{1} \mathrm{H}$ NMR $(300 \mathrm{MHz}$,

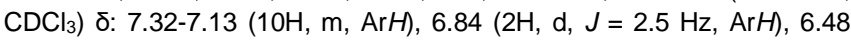


$(2 \mathrm{H}, \mathrm{dd}, J=8.5,2.6 \mathrm{~Hz}, \mathrm{ArH}), 6.23(2 \mathrm{H}, \mathrm{d}, J=8.5 \mathrm{~Hz}, \mathrm{ArH}), 5.18(2 \mathrm{H}, \mathrm{d}$, $\left.J=15.7 \mathrm{~Hz}, 2 \times \mathrm{CH}_{2}\right), 5.13-5.04\left(4 \mathrm{H}, \mathrm{m}, 2 \times \mathrm{HC}=\mathrm{CH}_{2}\right), 4.87-4.78(2 \mathrm{H}, \mathrm{m}$, $\left.2 \times H C=C_{2}\right), 4.45\left(2 \mathrm{H}, \mathrm{d}, J=15.7 \mathrm{~Hz}, 2 \times \mathrm{CH}_{2}\right), 3.82-3.70(2 \mathrm{H}, \mathrm{m}, 2 \mathrm{x}$ $\left.\mathrm{CH}_{2}\right), 3.62\left(6 \mathrm{H}, \mathrm{s}, 2 \times \mathrm{OCH}_{3}\right), 3.11\left(2 \mathrm{H}, \mathrm{dd}, J=15.4,4.3 \mathrm{~Hz}, 2 \mathrm{xCH}_{2}\right) ;{ }^{13} \mathrm{C}$ NMR $\left(75 \mathrm{MHz}, \mathrm{CDCl}_{3}\right)$ ): 176.9 (2xCO), 155.7, 136.3, 135.6, 132.6 129.7, 128.7, 127.5, 127.4, 119.4, 113.0, 111.3, 109.3, 56.2 (2xC), 55.7 $\left(2 \times \mathrm{OCH}_{3}\right), 43.9\left(2 \mathrm{xNCH}_{2}\right), 34.5\left(2 \times \mathrm{CCH}_{2}\right) ; \mathrm{MS}(\mathrm{EI}) \mathrm{m} / \mathrm{z}: 584\left(\mathrm{M}^{+}, 8 \%\right)$, 293 (33), 292 (96), 188 (13), 91 (100); HRMS (ESI): calcd. for $\mathrm{C}_{38} \mathrm{H}_{36} \mathrm{~N}_{2} \mathrm{O}_{4}$ : 584.2675; found 584.2682. Meso: could not be isolated.

See supporting information for additional details.

\section{Acknowledgments}

We gratefully acknowledge financial support from the Spanish Ministerio de Ciencia, Innovación y Universidades (projects CTQ2016-81893REDT, and RED2018-102387-T) the Spanish Ministerio de Economía, Industria y Competitividad, Agencia Estatal de Investigación (AEI) and Fondo Europeo de Desarrollo Regional (FEDER, EU) (projects CTQ2016-76782-P, CTQ201680375-P and CTQ2017-82935-P), the Generalitat Valenciana (PROMETEOII/2014/017), the University of Alicante, and Gobierno de Aragón (Group E06_17R and project LMP148_18). A. O.-M. thanks MINECO for a predoctoral fellowship.

Keywords: deacylative alkylation $\cdot$ deacylative bromination bioxindoles $\cdot$ iridium $\cdot$ photoredox catalysis

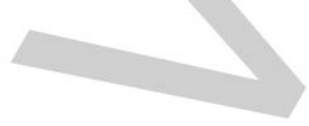


Entry for the Table of Contents (Please choose one layout)

Layout 1:

\section{FULL PAPER}

3,3'-Bioxindoles, precursors of a wide family of natural products, are prepared via deacylative alkylation or by photoredox catalysis. New deacylative bromination is reported.

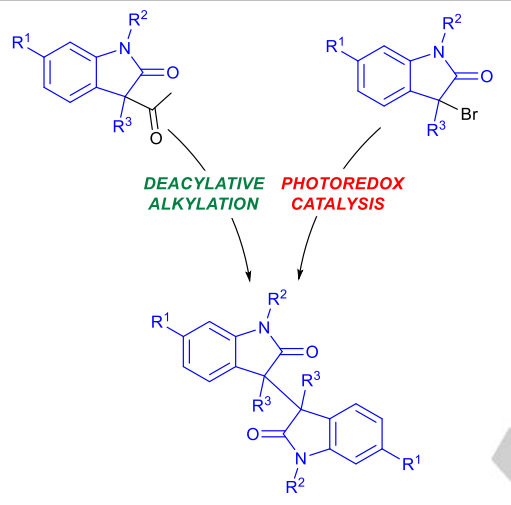

Cristina Moreno-Cabrerizo, Aitor Ortega-Martínez, Miguel A. Esteruelas, Ana M. López, Carmen Nájera, José M. Sansano

\section{Notes and references}

[1] a) Y.-L. Huang, W.-H. Bao, W.-W. Ying, W.-T. Chen, L.-H. Gao, X.-Y. Wang, G.-P. Chen, G.-P. Ge, W.-T. Wei, Synlett 2018, 29, 1485-1490; b) H. J. Lee, S. Lee, J. W. Lim, J. N. Kim, Bull. Korean Chem. Soc. 2013, 34, 2446-2450.

[2] These dimers were obtained as secondary products or prepared for confirming mechanistic pathways. a) H.-R. Wu, L. Cheng, D.-L. Kong, H.-Y. Huang, C.-L. Gu, L. Liu, D. Wang, C.-J. Li, Org. Lett. 2016, 18, 1382-1385; b) H.-R. Wu, H.-Y. Huang, C.-L. Ren, L. Liu, D. Wang, C.-J. Li, Chem. Eur. J. 2015, 21, 16744-16748; c) T. Niwa, S. Ishii, A. Hiramatsu, T. Osawa, Biosci. Biotechnol. Biochem, 2003, 67, 1870-1874; d) Y. Sohtome, M. Sugawara, D. Hashizume, D. Hojo, M. Sawamura, A. Muranaka, M. Uchiyama, M. Sodeoka, Heterocycles 2017, 95, 1030-1040; e) B. Cheng, B. Zu, Y. Li, S. Zhai, W. Xu, Y. Li, H. Zhaia, Adv. Synth. Catal. 2018, 360, $474-478$; f) A. Klasek, A. Lycka, M. Rouchal, O. Rudolf, A. Ruzicka, Helv. Chim. Acta, 2014, 97, 595-612; g) These dimers can be cleavage in the present of azocompounds: R. Ohnishi, M. Sugawara, M. Akakabe, T. Ezawa, H. Koshino, Y. Sohtome, M. Sodeoka, Asian J. Org. Chem. 2019, 8, 10171023; h) J.-J. Liu, H.-Y. Huang, L. Cheng, Q. Liu, D. Wang, L. Liu, Org. Biomol. Chem. 2018, 16, 899-903.

[3] a) S. Ghosh, S. Chaudhuri, A. Bisai, Org. Lett. 2015, 17, 1373-1376; b) N. Kumar, M. K. Das, S. Ghosh, A. Bisai, Chem. Commun. 2017, 53, 2170-2173; c) W. Xie, H. Wang, F. Fan, J. Tian, Z. Zuo, W. Zi, K. Gao, D. Maa, Tetrahedron Lett. 2013, 54, 4392-4396; d) D. Uraguchi, M. Torii, T. Ooi, ACS Catal. 2017, 7, 2765-2769; f) C.-L. Fang, S. Horne, N. Taylor, R. Rodrigo, J. Am. Chem. Soc. 1994, 116, 9480-9486.

[4] a) A. A. Shvets, S. V. Kurbatov, Chem. Heterocycl. Comp. 2009, 45, 866-867; b) W.-L. Chan, X. Tang, F. Zhang, G. Quek, G.-J. Mei, Y. Lu, Angew. Chem. Int. Ed. 2019, 58, $6260-6264$; c) A. Sanzone, P. Somfai, Eur. J. Org. Chem. 2015, 34413449; d) A. Hoang, K. Popov, P. Somfai, J. Org. Chem. 2017, 82, 2171-2176; e) J. Danielsson, P. Somfai, Org. Lett. 2014, 16, 784-787; f) H.-X. Ren, L. Peng, X.-J. Song, L.-G. Liao, Y. Zou, F. Tian, L.-X. Wang, Org. Biomol. Chem. 2018, 16, 12971304.

[5] a) C. Menozzi, P. I. Dalko, J. Cossy, Heterocycles 2007, 72, 199-205; b) L. E. Overman, E. A. Peterson, Angew. Chem. Int. Ed. 2003, 42, 2525 - 2528; c) L. E. Overman, E. A. Peterson, Tetrahedron Lett. 2003, 59, 6905-6919; d) S. B. Hoyt, L. E. Overman, Org. Lett. 2000, 2, 3241-3244; e) L. E. Overman, J. F. Larrow, B. A. Stearns, J. M. Vance, Angew. Chem. Int. Ed. 2000, 39, 213-215; f) B. M. Trost, M. Osipov, Angew. Chem. Int. Ed. 2013, 52, 9176 -9181; g) S.-K. Chen, W.-Q. Ma, Z.-B. Yan, F.-M. Zhang, S.-H. Wang, Y.-Q. Tu, X.-M. Zhang, J.-M. Tian, J. Am. Chem. Soc. 2018, 140, 10099-10103; h) H. Mitsunuma, M. Shibasaki, M. Kanai, S. Matsunaga, Angew. Chem. Int. Ed. 2012, 51, 5217-5221; i) S. De, M. K. Das, A. Roy, A. Bisai, J. Org. Chem. 2016, 81, 12258-12274; j) L. E. Overman, D.I V. Paone, J. Am. Chem. Soc. 2001, 123, 94659467.

[6] a) Y.-H. Jiang, R.-Y. Yang, J. Sun, C.-G. Yan, Heterocycl. Commun. 2016, 22, 151-156; b) Y.-Q. Zou, S.-W. Duan, X.-G. Meng, X.-Q. Hu, S. Gao, J.-R. Chen, W.-J. Xiao, Tetrahedron 2012, 68, 6914-6919; c) L.-L. Wu, G. H. Yang, Z. Guan, Y.-H. He, Tetrahedron 2017, 73, 1854-1860.

[7] a) P. K. Warghude, P. D. Dharpure, R. G. Bhat, Tetrahedron Lett. 2018, 59, 4076-4079; b) Y. Chen, B.-D. Cui, Y. Wang, W.-Y. Han, N.-W. Wan, M. Bai, W.-C. Yuan, Y.-Z. Chen, J. Org. Chem. 2018, 83, 10465-10475; c) For the reaction of the MBH system with itself, see: B. K. Min, S. Lee, H. J. Roh, J. Y. Ryu, J. Lee, J. N. Kim, Tetrahedron Lett. 2017, 58, 32513255.

[8] a) L.-J. Lu, Q. Fu, J. Sun, C.-G. Yan, Tetrahedron 2014, 70, 2537-2545; b) G.-L. Shen, J. Sun, C.-G. Yan, RSC Adv. 2015, 5, 4475-4483; c) L. Lu, C. Yan, Chin. J. Chem. 2015, 33, 1178-1188. 
[9] a) X.-L. Liu, Y. Gong, S. Chen, X. Zuo, Z. Yao, Y. Zhou, Org. Chem. Front. 2019, 6, 1603-1607; b) X.-Q. Zhu, J.-S. Wu, J.W. Xie, Tetrahedron 2016, 72, 8327-8334; c) J. Park, A. Jean, D. Y.-K. Chen, J. Org. Chem. 2018, 83, 6936-6957; d) J. Park, A. Jean, D. Y.-K. Chen, Angew. Chem. Int. Ed. 2017, 56, 14237-14240.

[10] G. Shanthi, P. T. Perumal, Tetrahedron Lett. 2008, 49, 7139-7142.

[11] L.-J. Lu, C.-G. Yan, Tetrahedron 2014, 70, 9587-9591.

[12] F. H. Osman, F. A. El-Samahy, Tetrahedron 2000, 56, 1863-1871.

[13] For other approach using these starting materials, see: K. A. P. Lingam, P. Shanmugam, K. Selvakumar, Synlett 2012, $23,278-284$.

[14] a) L. K. Kinthada, S. R. Medisetty, A. Parida, K. N. Babu, A. Bisai, J. Org. Chem. 2017, 82, 8548-8567; b) K. N. Babu, L. K. Kinthada, P. P. Das, A. Bisai, Chem. Commun. 2018, 54, 7963-7966; c) R. Liu, J. Zhang, Org. Lett. 2013, 15, 2266-2269; d) K. N. Babu, A. Roy, M. Singh, A. Bisai, Org. Lett. 2018, 20, 6327-6331; e) C. Guo, J. Song, J.-Z. Huang, P.-H. Chen, S.W. Luo, L.-Z. Gong, Angew. Chem. Int. Ed. 2012, 51, $1046-1050 ;$ f) S.-J. Han, F. Vogt, S. Krishnan, J. A. May, M. Gatti, S. C. Virgil, B. M. Stoltz, Org. Lett. 2014, 16, 3316-3319; g) D.-F. Chen, F. Zhao, Y. Hu, L.-Z. Gong, Angew. Chem. Int. Ed. 2014, 53, $10763-10767$; h) S. Ghosh, S. Chaudhuri, A. Bisai, Chem. Eur. J. 2015, 21, $17479-17484$; i) J. R. Fuchs, R. L. Funk, J. Am. Chem. Soc. 2004, 126, 5068-5069.

[15] a) S. Ghosh, S. Bhunia, B. N. Kakde, S. De, A. Bisai, Chem. Commun. 2014, 50, 2434-2437; b) N. Kikue, T. Takahashi, H. Nishino, Heterocycles 2015, 90, 540 - 562; c) N. Kumar, S. Ghosh, S. Bhunia, A. Bisai, Beilstein J. Org. Chem. 2016, 12, 1153-1169; d) S. Ghosh, S. De, B. N. Kakde, S. Bhunia, A. Adhikary, A. Bisai, Org. Lett. 2012, 14, 5864-5867.

[16] a) L. E. Overman, D. V. Paone, B. A. Stearns, J. Am. Chem. Soc. 1999, 121, 7702-7703; b) L. E. Overman, D. A. Watson, J. Org. Chem. 2006, 71, 2587-2599; c) L. E. Overman, D. A. Watson, J. Org. Chem. 2006, 71, 2600-2608; d) T. Kukosha, N. Trufilkina, M. Katkevics, Synlett 2011, 2525-2528; e) X. Shen, Y. Zhou, Y. Xi, J. Zhao, H. Zhang, Chem. Commun. 2015, 51, 14873-14876.

[17] This synthesis was performed using different approach: S. P. Lathrop, M. Movassaghi, Chem. Sci. 2014, 5, 333-340.

[18] C. R. Jamison, J. J. Badillo, J. M. Lipshultz, R. J. Comito, D. W. C. MacMillan, Nature Chem. 2017, 9, 1165-1169.

[19] R. K. Duke, R. D. Allan, G. A. R. Johnston, K. N. Mewett, A. D. Mitrovic, C. C. Duke, T.W. Hambley, J. Nat. Prod. 1995, 58, 1200 - 1208;

[20] M. Nakajima, C. Tsukano, M. Yasui, Y. Takemoto, J. Antibiot. 2019, 72, 407-419.

[21] S. Tadano, Y. Sugimachi, M. Sumimoto, S. Tsukamoto, H. Ishikawa, Chem. Eur. J. 2016, 22, 1277-1291.

[22] A. Ortega-Martínez, C. Molina, C. Moreno-Cabrerizo, J. M. Sansano, C. Nájera, Eur. J. Org. Chem. 2018, $2394-2405$.

[23] a) A. Ortega-Martínez, C. Molina, C. Moreno-Cabrerizo, J. M. Sansano, C. Nájera, Synthesis, 2017, 49, 5203-5210; b) A. Ortega-Martínez, C. Molina, C. Moreno-Cabrerizo, J. M. Sansano and C. Nájera, An. Acad. Bras. Cienc. 2018, 90, 10891099; c) A. Ortega-Martínez, R. de Lorenzo, J. M. Sansano, C. Nájera, Tetrahedron 2018, 74, 253-259; d) C. Molina, A. Ortega-Martínez, J. M. Sansano, C. Nájera, Org. Biomol. Chem. 2019, 17, 482-489.

[24] W.-L. Jia, J. J. Yang, X.-W. Gao, Q. Liu, L.-Z. Wu, J. Org. Chem. 2016, 81, 7172-7181.

[25] C. Ma, D. Xing, W. Hu, Org. Lett. 2016, 18, 3134-3137.

[26] R. Zhou, R. Liu, K. Zhang, L. Han, H. Zhang, W. Gao, R. Li, Chem. Commun. 2017, 53, 6860-6863.

[27] R. G. Alabau, B. Eguillor, J. Esler, M. A. Esteruelas, M. Oliván, E. Oñate, J.-Y. Tsai, C. Xia, Organometallics 2014, 33, 5582-5596.

[28] M. A. Esteruelas, A. M. López, E. Oñate, A. San-Torcuato, J.-Yi Tsai, C. Xia, Inorg. Chem. 2018, 57, 3720-3730.

[29] M. A. Esteruelas, D. Gómez-Bautista, A. M. López, E. Oñate, J.-Y. Tsai, C. Xia, Chem. Eur. J. 2017, 23, $15729-15737$.

[30] R. Castro-Rodrigo, M. A. Esteruelas, D. Gómez-Bautista, V. Lezáun, A. M. López, M. Oliván, E. Oñate, Organometallics 2019, 38, 3707-3718.

[31] Y. Q. Zou, W. Guo, F. L. Liu, L. Q. Lu, J. R. Chen, W. J. Xiao, Green Chem. 2014, 16, 3787-3795. 